\title{
3. COMPOSITION AND CRYSTALLIZATION TEMPERATURES OF PRIMARY MELTS FROM HOLE 896A BASALTS: EVIDENCE FROM MELT INCLUSION STUDIES ${ }^{1}$
}

\author{
Andrew W. McNeill ${ }^{2}$ and Leonid V. Danyushevsky²
}

\begin{abstract}
Glass and mineral geochemical data are presented for basalts from Ocean Drilling Program (ODP) Hole 896A. Phenocryst assemblages are dominated by calcic plagioclase $\left(\mathrm{An}_{76-945}\right)$ with olivine $\left(\mathrm{Fo}_{80-91.6}\right), \mathrm{Cr}-\mathrm{Al}$ spinel, and clinopyroxene. The origin of the calcic plagioclase phenocrysts was investigated by heating-stage experiments on silicate melt inclusions in plagioclase and olivine mineral separates. Trapping temperatures of $1195^{\circ}-1215^{\circ} \mathrm{C}$ are inferred for plagioclase $\left(\mathrm{An}_{83-94.5}\right)$. Inclusion compositions, interpreted to be in equilibrium with host plagioclase, are similar to the range of pillow-rim glasses from this hole. Primary melts, in equilibrium with $\mathrm{Fo}_{916,6}$ are estimated to have $\sim 15 \mathrm{wt} \% \mathrm{MgO}$ and crystallization temperatures of $\sim 1340^{\circ} \mathrm{C}$.
\end{abstract}

\section{INTRODUCTION}

High anorthite contents (to $\mathrm{An}_{94,5}$ ) are a characteristic feature of plagioclase phenocrysts from basalts drilled near the Costa Rica Rift in Ocean Drilling Program (ODP) Holes 504B and 896A. Plagioclases of similar composition have been reported from a variety of midocean ridge basalts (MORB); the Mid-Atlantic Ridge (Deep Sea Drilling Project Leg 37, Aumento, Melson, et al., 1977; Donaldson and Brown, 1977; FAMOUS, Stakes et al., 1984), the South East Indian Ridge (Price et al., 1986), the East Pacific Rise (Siqueiros Fracture Zone; Natland, 1989), and the Galapagos Platform (Sinton et al., 1993), and are commonly associated with megacrysts of Cr-rich magnesian diopside, forsteritic $\left(\mathrm{Fo}_{88-91}\right)$ olivine, and $\mathrm{Cr}$ - $\mathrm{Al}$ spinel.

Experimental results suggest that melts with $\mathrm{CaO} / \mathrm{Na}_{2} \mathrm{O}>10$ are required to crystallize plagioclase of $>\mathrm{An}_{90}$ under anhydrous conditions at pressures of < 5 kbar (Fisk, 1984; Panjasawatwong, 1991), although more recent data show that high melt $\mathrm{Al}_{2} \mathrm{O}_{3}$ will stabilize high-An plagioclase at lower $\mathrm{CaO} / \mathrm{Na}_{2} \mathrm{O}$ (Haskall et al., 1993; Panjasawatwong et al., 1995).

A survey of primitive MORB glass compositions from the literature (T.J. Falloon, pers. comm., 1994) indicates that only one (glass 212; Melson et al., 1976) has the necessary $\mathrm{CaO} / \mathrm{Na}_{2} \mathrm{O}$ to crystallize plagioclase of $\sim A n_{90}$, but not higher. The paucity of erupted liquids of this composition may be explained by pre-eruption processes (magma mixing, low-pressure fractionation, and magma chamber density filters; Sinton and Detrick, 1992). However, samples of such a liquid may be retained in melt inclusions trapped during growth of early formed phenocrysts, and such inclusions have been reported in the literature (e.g., Danyushevsky et al., 1988; Sobolev and Shimizu, 1993).

Two approaches have been employed in the study of melt inclusions. The first involves analysis of naturally quenched inclusions (e.g., Anderson, 1974; Clocchiatti, 1977; Falloon and Green, 1986; Natland, 1989). The compositions of such melt inclusions have been modified to varying degrees by post-trapping crystallization; however, ratios of elements incompatible with the host are thought to preserve some of the chemical signature of the parental melt. In addition, trapping temperatures are difficult to estimate because of uncertainty

'Alt, J.C., Kinoshita, H., Stokking, L.B., and Michael, P.J. (Eds.), 1996. Proc. $O D P$, Sci. Results, 148: College Station, TX (Ocean Drilling Program).

${ }^{2}$ Geology Department, University of Tasmania, Hobart, G.P.O. Box 252c, Tasmania 7001. Australia. McNeill: andrew.mcneill@geol.utas.edu.au; Danyushevsky: 1.dan@geol.utas.edu.au regarding the amounts and compositions of minerals formed by posttrapping crystallization.

The second approach, experimental studies of melt inclusions, involves reheating the inclusions to melt-back phases formed by posttrapping crystallization and thereby "homogenizing" the inclusion. Homogenization is defined as the moment of dissolution of the last phase inside an inclusion, normally a shrinkage gas bubble, producing a homogeneous melt (Roedder, 1984). In an ideal fluid-saturated system the composition of the inclusion at the moment of homogenization is equal to that of the trapped melt, and the temperature of homogenization matches the temperature of trapping. Two techniques are employed; heating in a 1-atm furnace, under controlled oxygen fugacity (Sinton et al., 1993; Johnson et al., 1995), or in a visually controlled heating stage with a pure He atmosphere (Sobolev et al., 1980).

In this contribution we document the petrography and major element geochemistry of glass and phenocryst phases from Hole 896A basalts, and use heating-stage experiments on plagioclase and olivine to determine the trapping temperature and chemistry of silicate melt inclusions. From these data we estimate melt compositions in equilibrium with plagioclase $\mathrm{An}_{94.5}$ and model possible primary magmas.

\section{ANALYTICAL AND EXPERIMENTAL TECHNIQUES}

Glass samples were carefully picked from pillow rims, mounted in epoxy, and polished. The glasses and any phenocryst phases present were then analyzed by electron microprobe. Seven samples were selected on the basis of analyzed glass chemistry and phenocryst abundance, and mineral separates were prepared by crushing and sieving. Phenocrysts were picked from the $0.3-$ to $1.0-\mathrm{mm}$ size fraction, mounted in epoxy and polished. Between 120 and 190 plagioclase grains in each sample and all olivine, spinel, and, where present, clinopyroxene were analyzed to establish the range of phenocryst compositions for each sample.

\section{Electron Microprobe Analysis}

All analyses were done on an automated three-spectrometer Cameca SX-50 microprobe at the University of Tasmania, Central Science Laboratory. Standards used were San Carlos Olivine (USNM 111312/444), plagioclase LPL (USNM 115900), Augite KA (USNM122142) (Jarosewich et al., 1980), spinel UV-126 (Lavrentev et al., 1974), and basaltic glass VG-2 (USNM 111249/52). Analytical conditions and counting times for each analytical label used are given 
Table 1. Electron microprobe experimental conditions.

\begin{tabular}{|c|c|c|c|c|c|}
\hline \multirow[b]{2}{*}{ Oxide } & \multicolumn{5}{|c|}{ Count times (peak/background: s) } \\
\hline & Plagioclase & Olivine & Pyroxene & Spinel & Glass \\
\hline $\mathrm{SiO}_{2}$ & $10 / 5$ & $10 / 5$ & $10 / 5$ & $10 / 5$ & $10 / 5$ \\
\hline $\mathrm{TiO}_{2}^{-}$ & & & $10 / 5$ & $20 / 10$ & $10 / 5$ \\
\hline $\mathrm{Al}_{2} \mathrm{O}_{3}$ & $10 / 5$ & & $10 / 5$ & $20 / 10$ & $10 / 5$ \\
\hline $\mathrm{FeO}$ & $20 / 10$ & $20 / 10$ & $20 / 10$ & $20 / 10$ & $20 / 10$ \\
\hline $\mathrm{MnO}$ & & $20 / 10$ & $20 / 10$ & $20 / 10$ & $10 / 5$ \\
\hline $\mathrm{MgO}$ & $10 / 5$ & $10 / 5$ & $10 / 5$ & $10 / 5$ & $10 / 5$ \\
\hline $\mathrm{CaO}$ & $10 / 5$ & $20 / 10$ & $10 / 5$ & & $10 / 5$ \\
\hline $\mathrm{Na}_{2} \mathrm{O}$ & $10 / 5$ & & $10 / 5$ & & $10 / 5$ \\
\hline $\mathrm{K}_{2} \mathrm{O}$ & $20 / 10$ & & & & $20 / 10$ \\
\hline $\mathrm{P}_{2} \mathrm{O}_{5}$ & & & & & $10 / 5$ \\
\hline $\mathrm{Cr}_{2} \mathrm{O}_{3}$ & & $20 / 10$ & $20 / 10$ & $10 / 5$ & $10 / 5$ \\
\hline $\mathrm{NiO}$ & & $20 / 10$ & & $10 / 5$ & \\
\hline $\mathrm{ZnO}$ & & & & $10 / 5$ & \\
\hline Voltage (kv) & 15 & 15 & 15 & 15 & 15 \\
\hline Current (nA) & 0 & 20 & 20 & 20 & 20 \\
\hline Beam $(\mu \mathrm{m})$ & 1 & 1 & 1 & 1 & $5 \times 8$ \\
\hline
\end{tabular}

Note: Blank spaces indicate that element was not analyzed.

in Table 1. Relevant standards were analyzed at the start and end of each session, and at approximately 4-hr intervals during longer sessions. Each standard analysis is the average of three analyses, mineral and melt inclusion analyses are averages of two points, and glass analyses are averages of four points.

\section{Fourier Transform Infrared Analysis}

The $\mathrm{H}_{2} \mathrm{O}$ contents of glass samples were determined by Fourier transform infrared spectroscopy (FTIR) using a Bruker IFS 66 spectrometer with attached optical microscope and Bruker Opus/IR data reduction software at the Central Science Laboratory, University of Tasmania. The same glass chips used for electron microprobe analysis were used for FTIR analysis. Sample preparation, standards, and experimental conditions used have been described elsewhere (Danyushevsky et al., 1993).

\section{High-temperature Microthermometry}

Grain mounts used for electron microprobe analysis were cut and polished to 250-350 $\mu \mathrm{m}$ thickness and grains hosting primary melt inclusions suitable for microthermometry were extracted. The heating stage used is an optically controlled system using a high-purity He atmosphere, the same as that described by Sobolev et al. (1980). This stage design allows more rapid quenching than with commercially designed equipment. Using visual control and experimental techniques developed at Vernadsky Institute of Geochemistry, Moscow, homogenization temperatures $\left(T_{h}\right)$ may be estimated to within $\pm 10^{\circ}-20^{\circ} \mathrm{C}$ (Sobolev, 1983; Sobolev et al., 1989).

Following the technique referenced above, the sample phenocryst was placed on a $200-$ to $300-\mu \mathrm{m}$ thick plate of transparent, refractory mantle olivine and a small piece of Au was placed on the sample grain as close as possible to the inclusions of interest. The melting point of Au was used to calibrate temperature during each run. The sample was then placed on a $\mathrm{Pt}$ ring inside the tubular $\mathrm{Pt}_{90} \mathrm{Rh}_{10}$ foil heater; the heating stage was sealed and then flushed with $\mathrm{He}$ for 5$6 \mathrm{~min}$ before heating began.

Both plagioclase and olivine were heated rapidly to $1150^{\circ} \mathrm{C}$ and then at a rate of $5^{\circ} \mathrm{C}$ per min, as determined from a series of kinetic experiments on plagioclase, until close to $T_{h}$, as assessed by observing small $(\sim 10 \mu \mathrm{m}$ diameter) inclusions in plagioclase and small (10$20 \mu \mathrm{m}$ ) inclusions in olivine. Temperature was then held constant or increased slightly until the inclusions of interest were homogenized, Time at high temperature $\left(>1190^{\circ} \mathrm{C}\right)$ was limited to $<6 \mathrm{~min}$ for plagioclase, as it was found that if an inclusion did not homogenize within this time then it was unlikely to homogenize in a reasonable time (i.e., $<1 \mathrm{hr}$ ). After an experiment, each grain was mounted in epoxy

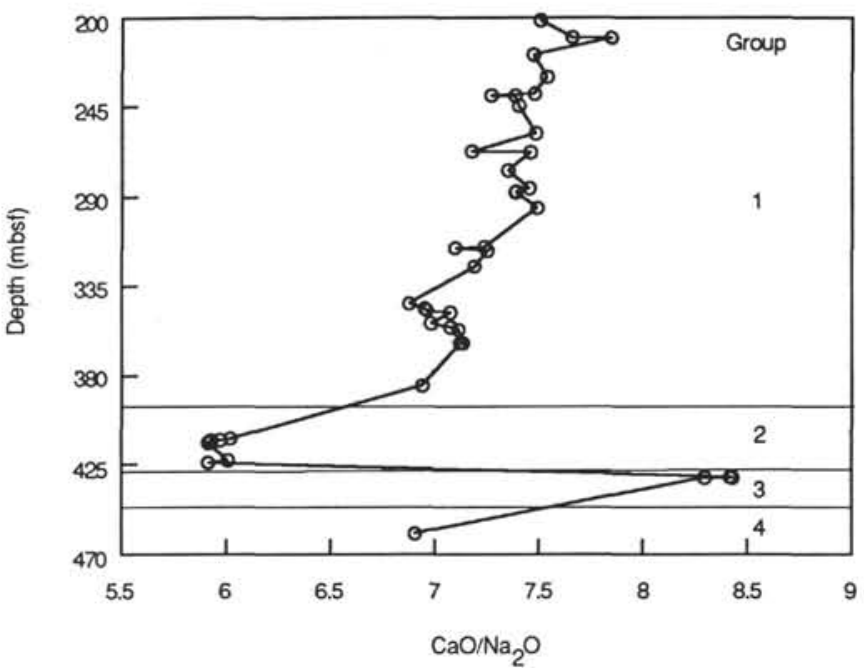

Figure 1. Downhole variations in glass $\mathrm{CaO} / \mathrm{Na}_{2} \mathrm{O}$. Glass groups are based both on $\mathrm{CaO} / \mathrm{Na}_{2} \mathrm{O}$ values and variations in elements shown on Figure 2.

and polished until the inclusions of interest were exposed and these were then analyzed.

\section{RESULTS \\ Glass Chemistry}

Major element analyses of 43 glasses, forming a stratigraphic section of Hole 896A, are summarized in Figures 1 and 2. Full analyses are presented in Fisk et al. (this volume). On the basis of these data, the drilled section was divided into four intervals with samples from each interval forming subsequent groups: Group 1 comprised samples from Cores 148-896A-1R to 20R, Group 2 from Cores 148896A-25R and 26R, Group 3 from Core 148-896A-27R, and Group 4 from Core 148-896A-30R. The transition from Group 1 to 2 occurs across the massive flow of Cores 148-896A-20R to $24 \mathrm{R}$, and transitions between the lower groups are in pillow lava sequences and appear over $2 \mathrm{~m}$ of core. These transitions do not appear to correlate with changes in either phenocryst assemblage or abundance, as defined by shipboard logging. Most samples are from Groups I and 4. These two groups form a single trend on element-MgO plots, consistent with olivine-plagioclase co-crystallization. Glasses from Group 2 have higher $\mathrm{Na}_{2} \mathrm{O}, \mathrm{TiO}_{2}$, and $\mathrm{Al}_{2} \mathrm{O}_{3}$ compared with the main trend (Fig. 2) whereas those from Group 3 have higher $\mathrm{MgO}, \mathrm{CaO}$, and $\mathrm{FeO}$, and lower $\mathrm{Al}_{2} \mathrm{O}_{3}$ and $\mathrm{Na}_{2} \mathrm{O}$ than the main trend.

The $\mathrm{H}_{2} \mathrm{O}$ contents of pillow-rim glasses are all $<0.1 \%$ and there is no variation of $\mathrm{H}_{2} \mathrm{O}$ content between the glass groups, within the precision of the technique used. These low abundances are consistent with analyses of glasses of similar $\mathrm{Mg \#}(=100 \times \mathrm{Mg} /[\mathrm{Mg}+\mathrm{Fe}])$ and $\mathrm{K}_{2} \mathrm{O}$ from the East Pacific Rise and Galapagos Ridge (Byers et al., 1986; Michael, 1988).

Seven glasses, all from the high $\mathrm{MgO}$ part of the suite, from Groups 1, 2, and 3 were selected for microthermometry (Table 2). The following discussion of mineralogy and melt inclusion compositions refers only to these samples.

\section{Petrography and Phenocryst Mineral Chemistry}

The petrography of Hole 896A basalts has been described in detail by the Shipboard Scientific Party (1993) and only the major characteristics of selected samples are summarized here. The samples used are all from glassy pillow rims and inner variolitic zones, and they 


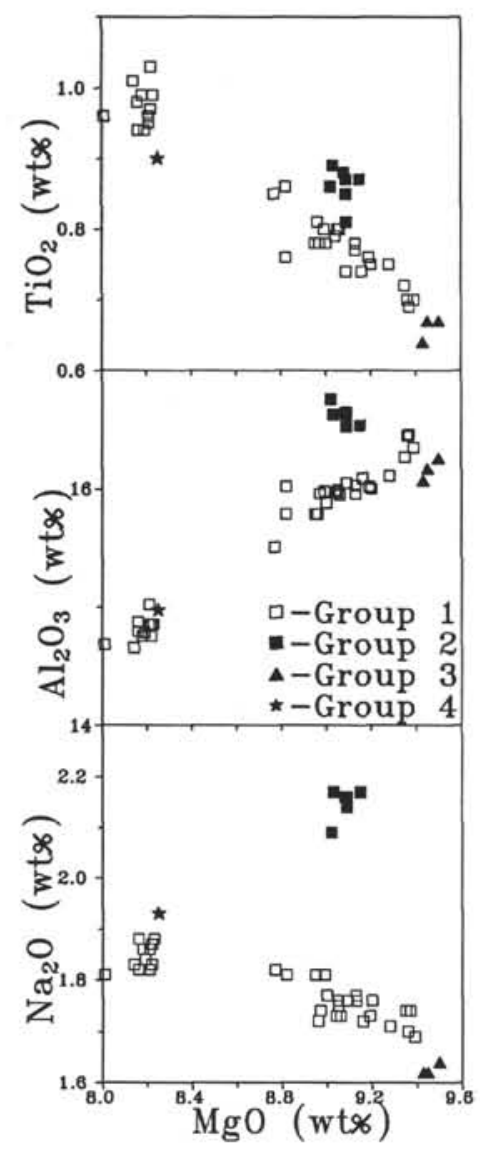

Figure 2. Selected major oxides vs. MgO for Hole 896A pillow-rim glass samples. Glass groups have been defined on the basis of these variations and $\mathrm{CaO} / \mathrm{Na}_{2} \mathrm{O}$ as shown on Figure 1 .

Table 2. Analyses of representative pillow-rim glass samples from Hole 896A.

\begin{tabular}{|c|c|c|c|c|c|c|c|}
\hline $\begin{array}{l}\text { Core, section: } \\
\text { Interval }(\mathrm{cm}): \\
\text { Piece no.: } \\
\text { Glass group: } \\
\text { Depth (mbsf): }\end{array}$ & $\begin{array}{c}3 R-1 \\
16-18 \\
4 \\
1 \\
210.1\end{array}$ & $\begin{array}{c}4 R-1 \\
10-13 \\
2 \\
1 \\
219.0\end{array}$ & $\begin{array}{c}9 \mathrm{R}-1 \\
125-130 \\
24 \\
1 \\
267.95\end{array}$ & $\begin{array}{c}25 R-1 \\
89-93 \\
11 \\
2 \\
412.2\end{array}$ & $\begin{array}{c}25 \mathrm{R}-2 \\
61-64 \\
11 \\
2 \\
413.4\end{array}$ & $\begin{array}{c}27 R-1 \\
105-109 \\
13 \\
3 \\
431.6\end{array}$ & $\begin{array}{c}27 \mathrm{R}-1 \\
124-130 \\
15 \\
3 \\
431.8\end{array}$ \\
\hline $\mathrm{SiO}_{2}$ & 48.94 & 49.11 & 49.68 & 48.96 & 49.24 & 49.28 & 49.03 \\
\hline $\mathrm{TiO}_{2}^{2}$ & 0.70 & 0.72 & 0.81 & 0.87 & 0.85 & 0.67 & 0.64 \\
\hline $\mathrm{Al}_{2} \mathrm{O}_{3}$ & 16.45 & 16.27 & 15.79 & 16.53 & 16.55 & 16.17 & 16.07 \\
\hline $\mathrm{FeO}$ & 8.73 & 8.80 & 9.03 & 8.99 & 9.17 & 9,26 & 9.12 \\
\hline $\mathrm{MnO}$ & 0.12 & 0.15 & 0.14 & 0.16 & 0.15 & 0.13 & 0.12 \\
\hline $\mathrm{MgO}$ & 9.36 & 9.35 & 8.96 & 9.09 & 9.09 & 9.45 & 9.43 \\
\hline $\mathrm{CaO}$ & 13.02 & 13.00 & 12.83 & 12.89 & 12.81 & 13.64 & 13.66 \\
\hline $\mathrm{Na}_{2} \mathrm{O}$ & 1.70 & 1.74 & 1.72 & 2.14 & 2.16 & 1.62 & 1.62 \\
\hline $\mathrm{K}_{2} \mathrm{O}$ & 0.02 & 0.03 & 0.01 & 0.02 & 0.02 & 0.02 & 0.02 \\
\hline $\mathrm{P}_{2} \mathrm{O}_{5}$ & 0.04 & 0.04 & 0.05 & 0.03 & 0.05 & 0.03 & 0.03 \\
\hline $\mathrm{Cr}_{2} \mathrm{O}_{3}$ & 0.07 & 0.05 & 0.07 & 0.07 & 0.05 & 0.05 & 0.07 \\
\hline $\mathrm{H}_{2} \mathrm{O}$ & 0.07 & 0.07 & 0.08 & 0.08 & 0.08 & 0.05 & 0.05 \\
\hline Total & 99.22 & 99.33 & 99.17 & 99.83 & 100.22 & 100.37 & 99.86 \\
\hline Mg\# & 65.7 & 65.6 & 64.0 & 64.4 & 64.0 & 64.7 & 65.0 \\
\hline $\mathrm{CaO} / \mathrm{Na}_{2} \mathrm{O}$ & 7.7 & 7.5 & 7.5 & 6.0 & 5.9 & 8.4 & 8.4 \\
\hline
\end{tabular}

Notes: See text for details on glass groups. All Fe as FeO. $\mathrm{Mg} \#=100 \times[\mathrm{Mg} /(\mathrm{Mg}+$ $\mathrm{Fe})]$.

range from sparsely porphyritic ( $1 \%-2 \%$ phenocrysts) to highly porphyritic ( $>10 \%$ phenocrysts). Throughout most of the drilled section, and in all samples used in this study, plagioclase is the dominant phenocryst phase, with lesser olivine (fresh only in glassy rims), clinopyroxene, and spinel. Shipboard descriptions indicate that clinopyroxene phenocrysts are restricted to the interval $353.1-387.5 \mathrm{~m}$ below seafloor (mbsf) (Cores 148-896A-18R to 22R); however, we recovered grains of phenocrystal pyroxene (high $\mathrm{Mg} \#$ and $\mathrm{Cr}_{2} \mathrm{O}_{3}$ ) from Cores 148-896A-9R, 25R and 27R, suggesting that it is more widespread but in low abundances.

\section{Plagioclase}

Plagioclase occurs as anhedral to euhedral phenocrysts that range from 0.1 to $5 \mathrm{~mm}$, with those $>0.9 \mathrm{~mm}$ interpreted to be megacrysts on the basis of crystal size distribution patterns (Shipboard Scientific Party, 1993). Plagioclase occurs as single crystals, in glomerocrysts with olivine and/or clinopyroxene, and may be included in olivine and in the rims of some clinopyroxenes. Red-brown spinel and glass inclusions are common. Plagioclase phenocrysts commonly have striking optical zoning, and are both normally and reversely zoned. These zoning patterns are described in detail by Shipboard Scientific Party (1993).

Plagioclase "core" compositions range from $\mathrm{An}_{78}$ to $\mathrm{An}_{94.5}$ (Table 3; Fig. 3) and are similar to those from the extrusive section of nearby Hole 504B (Natland et al., 1983). However, most samples host plagioclase grains of up to $\mathrm{An}_{92-93}$ only, and plagioclases of $>\mathrm{An}_{93}$ were found only in Sample 148-896A-9R-1 (Piece 24). Despite the wide range of plagioclase compositions in each sample, histograms of An content (Fig. 3) are characterized by well-defined maxima that are statistically indistinguishable from the arithmetic means of An content for each sample. To check if these maxima reflect compositions of plagioclases in equilibrium with the host glasses, the arithmetic mean of An content is plotted vs. the $\mathrm{CaO} / \mathrm{Na}_{2} \mathrm{O}$ of the host glass on Figure 4. Two observations can be made: (1) samples from each pillow-rim glass group, with similar $\mathrm{CaO} / \mathrm{Na}_{2} \mathrm{O}$, are characterized by similar mean plagioclase compositions; and (2) an increase in melt $\mathrm{CaO} / \mathrm{Na}_{2} \mathrm{O}$ with increasing $\mathrm{An}$ is consistent with low-pressure experimental data on plagioclase-melt equilibria. This indicates that most plagioclases from each sample are in equilibrium with their host glasses.

\section{Olivine}

Olivine phenocrysts were separated from all samples except Sample 148-896A-4R-1 (Piece 2), and representative analyses are given in Table 4 . They generally compose $<4 \%$ of the sample and range in size from 0.1 to $5 \mathrm{~mm}$. The olivines are euhedral, commonly with skeletal overgrowths, and may include spinel, plagioclase, and glass. The phenocrysts are unzoned, with variations of $<1$ Fo unit from core to rim. As with the plagioclase phenocrysts, olivines also have a significant compositional range, from $\mathrm{Fo}_{80}$ to $\mathrm{Fo}_{91.6}$, and a well-defined distribution maximum. However, unlike the plagioclases all samples used have this maximum at the same Fo of $87-89$ ( $86 \%$ of analyses). The $\mathrm{Mg} \#$ values of all seven glasses are very similar (64-65.7). Assuming an olivine-melt $\mathrm{Mg}-\mathrm{Fe}^{2+} \mathrm{K}_{\mathrm{d}}$ of 0.3 , liquids in equilibrium with olivines $\sim \mathrm{Fo}_{88}$ (the most abundant Fo of studied samples) should have an $\mathrm{Mg}^{\prime}\left(=100 \times \mathrm{Mg} /\left[\mathrm{Mg}+\mathrm{Fe}^{2+}\right]\right)$ of 68.8 . To obtain this result, the $\mathrm{Fe}^{3+} / \Sigma \mathrm{Fe}$ of the studied glasses should be $\sim 0.17$. This value is significantly higher than expected for normal MORB (Christie et al., 1986; Michael and Chase, 1987), suggesting that the dominant olivine compositions $\left(\mathrm{FO}_{87-89}\right)$ are not in equilibrium with the host glasses and, most likely, are crystallized from more primitive melts. Assuming a more realistic $\mathrm{Fe}^{3+} / \Sigma \mathrm{Fe}$ of $0.10-0.09$, the calculated olivine in equilibrium with the studied glasses is $\mathrm{Fo}_{86-87}$.

We note also that plagioclase inclusions analyzed from five olivine phenocrysts $\left(\mathrm{Fo}_{88-88.8}\right)$ have a wide compositional range $\left(\mathrm{An}_{86,3-}\right.$ ${ }_{92.3}$ ); significantly, this range of compositions occurs in a single olivine (see Table 3 ).

\section{Spinel}

Spinels are a minor component of the phenocryst assemblage in all samples examined, occurring as phenocrysts and inclusions in plagioclase and olivine. Grain size ranges from 10 to $150 \mu \mathrm{m}$. Representative analyses are included in Table 5 . Spinels show a well-defined 
Table 3. Representative plagioclase analyses, Hole 896A.

\begin{tabular}{|c|c|c|c|c|c|c|c|c|c|c|c|c|c|}
\hline Analysis no.: & 1 & 2 & 3 & 4 & 5 & 6 & 7 & 8 & 9 & 10 & 11 & 12 & 13 \\
\hline $\mathrm{SiO}_{2}$ & 44.58 & 46.38 & 44.67 & 46.16 & 47.40 & 43.92 & 44.02 & 45.19 & 47.31 & 46.26 & 45.72 & 46.37 & 44.66 \\
\hline $\mathrm{Al}_{2} \mathrm{O}_{3}$ & 34.63 & 33.77 & 35.08 & 34.46 & 33.72 & 35.07 & 35.06 & 34.29 & 32.56 & 33.71 & 34.46 & 33.52 & 34.70 \\
\hline $\mathrm{FeO}$ & 0.27 & 0.28 & 0.36 & 0.37 & 0.51 & 0.36 & 0.37 & 0.34 & 0.53 & 0.43 & 0.34 & 0.55 & 0.57 \\
\hline $\mathrm{MgO}$ & 0.20 & 0.31 & 0.20 & 0.27 & 0.24 & 0.16 & 0.14 & 0.23 & 0.40 & 0.21 & 0.28 & 0.25 & 0.19 \\
\hline $\mathrm{CaO}$ & 18.93 & 17.71 & 18.79 & 18.18 & 17.61 & 19.07 & 19.30 & 18.20 & 16.43 & 17.90 & 18.23 & 17.52 & 18.65 \\
\hline $\mathrm{Na}_{2} \mathrm{O}$ & 0.75 & 1.24 & 0.79 & 1.30 & 1.61 & 0.61 & 0.63 & 1.17 & 1.80 & 1.42 & 1.12 & 1.54 & 0.86 \\
\hline $\mathrm{K}_{2} \mathrm{O}$ & 0.00 & 0.00 & 0.00 & 0.01 & 0.00 & 0.01 & 0.00 & 0.01 & 0.04 & 0.01 & 0.01 & 0.00 & 0.00 \\
\hline Total & 99.36 & 99.69 & 99.89 & 100.75 & 101.09 & 99.20 & 99.52 & 99.43 & 99.07 & 99.94 & 100.16 & 99.75 & 99.63 \\
\hline \multicolumn{14}{|c|}{ Cations calculated on the basis of 8 oxygens } \\
\hline $\mathrm{Si}$ & 2.075 & 2.141 & 2.067 & 2.114 & 2.159 & 2.050 & 2.049 & 2.099 & 2.193 & 2.135 & 2.106 & 2.143 & 2.074 \\
\hline Al & 1.899 & 1.837 & 1.914 & 1.860 & 1.810 & 1.929 & 1.924 & 1.877 & 1.779 & 1.834 & 1.871 & 1.826 & 1.900 \\
\hline $\mathrm{Fe}$ & 0.011 & 0.011 & 0.014 & 0.014 & 0.019 & 0.014 & 0.014 & 0.013 & 0.021 & 0.017 & 0.013 & 0.021 & 0.022 \\
\hline $\mathrm{Mg}$ & 0.014 & 0.021 & 0.014 & 0.018 & 0.016 & 0.011 & 0.010 & 0.016 & 0.028 & 0.014 & 0.019 & 0.017 & 0.013 \\
\hline $\mathrm{Ca}$ & 0.944 & 0.876 & 0.932 & 0.892 & 0.859 & 0.954 & 0.963 & 0.906 & 0.816 & 0.885 & 0.900 & 0.868 & 0.928 \\
\hline $\mathrm{Na}$ & 0.068 & 0.111 & 0.071 & 0.115 & 0.142 & 0.055 & 0.057 & 0.105 & 0.162 & 0.127 & 0.100 & 0.138 & 0.077 \\
\hline K & 0.000 & 0.000 & 0.000 & 0.001 & 0.000 & 0.001 & 0.000 & 0.001 & 0.002 & 0.001 & 0.001 & 0.000 & 0.000 \\
\hline Total & 5.010 & 4.996 & 5.011 & 5.014 & 5.007 & 5.014 & 5.017 & 5.016 & 5.000 & 5.012 & 5.009 & 5.013 & 5.015 \\
\hline An & 93.3 & 88.8 & 92.9 & 88.5 & 85.8 & 94.5 & 94.4 & 89.5 & 83.3 & 87.4 & 89.9 & 86.3 & 92.3 \\
\hline$A b$ & 6.7 & 11.2 & 7.1 & 11.5 & 14.2 & 5.5 & 5.6 & 10.4 & 16.5 & 12.5 & 10 & 13.7 & 7.7 \\
\hline Or & 0.0 & 0.0 & 0.0 & 0.0 & 0.0 & 0.0 & 0.0 & 0.1 & 0.2 & 0.1 & 0.1 & 0.0 & 0.0 \\
\hline $\mathrm{Mg} \#$ & 56.9 & 66.4 & 49.8 & 56.5 & 45.6 & 44.2 & 40.3 & 54.7 & 57.4 & 46.5 & 59.5 & 44.8 & 37.3 \\
\hline
\end{tabular}

Notes: Alphanumeric codes following sample numbers are identifiers of grain mount and grain number. I = Sample 148-896A-9R-1 (Piece 24), A9-54 (hosts melt inclusion 1, Table 7). 2 = Sample 148-896A-9R-I (Piece 24), A9-21 (hosts melt inclusion 2, Table 7). $3=$ Sample I48-896A-27R-1 (Piece 15), AI3-I16 (hosts melt inclusion 3, Table 7). 4= Sample 148-896A-9R-I (Piece 24), 12-15 (hosts inclusion 4, Table 7). $5=$ Sample 148-896A-9R-I (Piece 24), I2-18 (hosts inclusion 5, Table 7). $6=$ Sample 148-896A-9R-I (Piece 24), A9-58, 7 = Sample 148-896A-9R-I (Piece 24), A9-113, $8=$ Sample 148-896A-27R-1 (Piece 15), A13-133 (hosts spinel I, Table 5), 9= Sample 148-896A-27R-I (Piece 15), A13-93 (hosts spinel 2, Table 5). 10 = Sample 148-896A-4R-1 (Piece 2). T-2 (hosts spinel 3, Table 5), II = Sample 148-896A-4R-1 (Piece 2), T-5 (hosts spinel 4, Table 5). 12 and $13=$ Sample 148-896A-27R-1 (Piece 15), AI3-88 (inclusion in olivine 1, Table 4).

trend of decreasing $\mathrm{Mg}^{\prime}$ with $\mathrm{Cr} \#(=100 \times \mathrm{Cr} /[\mathrm{Cr}+\mathrm{Al}])$ (Fig. $\left.5 \mathrm{~A}\right)$, similar to other MORB suites (e.g., Sigurdsson and Schilling, 1976), indicating that spinel crystallization accompanied olivine and plagioclase fractionation (Allan et al., 1988). Calculated $\mathrm{Fe}^{2+} / \mathrm{Fe}^{3+}$ values of all spinels have a narrow range, with an average of 2.2 (Fig. 5B). Although there is a possible trend of increasing $\mathrm{Fe}^{2+} / \mathrm{Fe}^{3+}$ with increasing $\mathrm{Cr}$, we think that the average $\mathrm{Fe}^{2+} / \mathrm{Fe}^{3+}$ is representative of this suite.

\section{Clinopyroxene}

Clinopyroxene is present as both phenocrysts and quenched crystals. Phenocrysts range from 0.5 to $7.0 \mathrm{~mm}$ long, are subhedral, often with a rounded or corroded form, and may partially enclose plagioclase phenocrysts (Shipboard Scientific Party, 1993). Representative analyses are given in Table 6 .

\section{Melt Inclusions}

Melt inclusions that would be classified as primary, secondary, and pseudo-secondary, using the criteria of Roedder (1984), occur in all phenocryst types. Inclusions in plagioclase and olivine were used in heating experiments, and are described in detail below.

Primary inclusions occur in $\sim 30 \%$ of plagioclase grains. They range from 2 to $350 \mu \mathrm{m}$ across and vary in shape from round to rounded negative crystal forms. The inclusions occur in three main patterns: randomly distributed in the cores of crystals having inclusionfree rims; scattered throughout the grain (often arranged parallel to, and elongate along, 010); and more rarely, concentrated in concentric zones. Inclusions that lack fluid bubbles are rare, as are daughter crystals, although sulfide blebs occur in some larger inclusions. Rarely, inclusions are associated with arcuate fractures in the host plagioclase. There are some downhole variations in inclusion occurrence; inclusions from samples higher in the hole (Cores 148-896A-3R, 4R, and $9 \mathrm{R}$ ) are typically larger (most large primary inclusions are 40 $350 \mu \mathrm{m}$ ), more rounded, and occur more commonly randomly distributed throughout the grains. Those from Cores 148-896A-25R and $27 \mathrm{R}$ are much smaller (generally $<40 \mu \mathrm{m}$ diameter), are associated with more fracturing than those from higher in the drilled section, occur concentrated in the cores of phenocrysts, and are more numerous.

Planes of 2- to 5- $\mu \mathrm{m}$ rounded inclusions, of larger irregularly shaped inclusions, some of which are linked by healed fractures, and of large $(>50 \mu \mathrm{m})$ irregularly shaped inclusions typically with crystallographic control, are the three main types of secondary and pseudo-secondary inclusion seen. The last type of inclusion commonly has a complex three-dimensional form and may comprise a large component, by volume, of the host crystal. These inclusions may result from rapid crystal growth, represent glass joining two crystals, or may result from resorption followed by rapid overgrowth; whatever the case, they are not useful for heating experiments and will not be discussed further.

Primary inclusions in olivine range from 10 to $500 \mu \mathrm{m}$ in diameter, but are generally $20-100 \mu \mathrm{m}$, and were recorded in $70 \%-80 \%$ of grains, although most phenocrysts host only one or two inclusions. Most inclusions lack vapor bubbles, have a round to rounded-tubular form, and are clear green to brown with only rare obvious daughter crystals. Composite inclusions (consisting of simultaneously trapped glass and plagioclase) were found in a single phenocryst from Sample 148-896A-25R-1, Piece 11. There appears to be no dominant crystallographic control on inclusion orientation.

Compositions of primary inclusions in plagioclase, olivine, and spinel, which were quenched during eruption as glass or glass with a fluid bubble (naturally quenched melt inclusions), are given in Table 7. The bulk compositions of these inclusions are variably modified by post-entrapment crystallization of overgrowths on the host mineral. As can be seen on Figure $6 \mathrm{~A}$, variations in $\mathrm{Al}_{2} \mathrm{O}_{3}$ and $\mathrm{MgO}$ content are much larger in naturally quenched inclusions than in pillow-rim glasses, and also define a trend perpendicular to that produced by cotectic olivine-plagioclase crystallization. Many inclusions in plagioclase have higher $\mathrm{MgO}$ and lower $\mathrm{Al}_{2} \mathrm{O}_{3}$ contents than the glasses, whereas inclusions in olivine show the opposite effect (i.e., increasing $\mathrm{Al}_{2} \mathrm{O}_{3}$, decreasing $\mathrm{MgO}$ ). These variations are interpreted to result from post-trapping overgrowths on the walls of inclusions. The field of pillow-rim glasses overlaps a small segment of the trend defined by the inclusions. This implies that inclusions which have compositions similar to the glasses are the least modified by post-trapping 

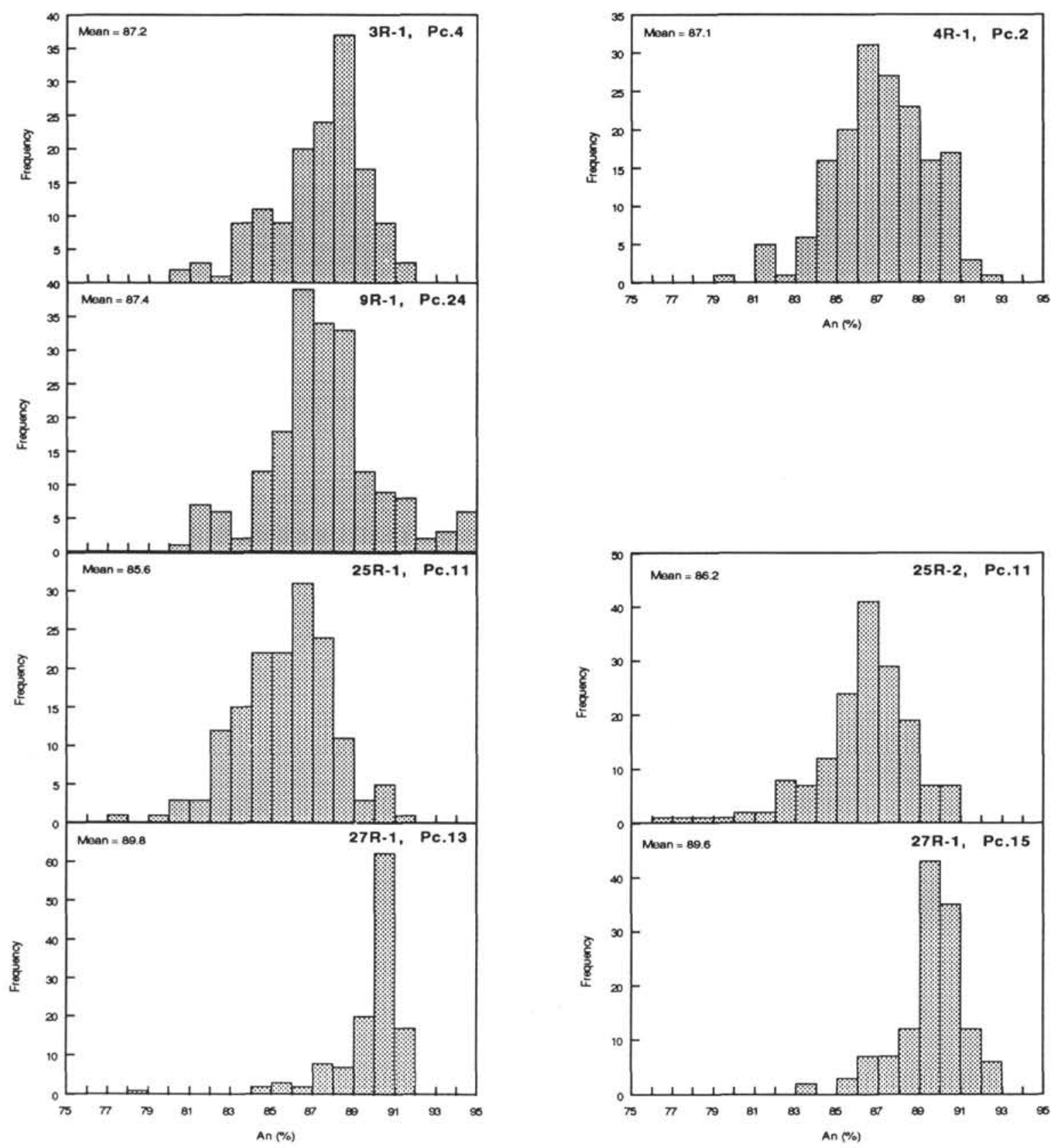

Figure 3. Histograms of plagioclase phenocryst composition from glass samples used in this study. Pc. = piece.

crystallization, and deviation of $\mathrm{MgO}$ (or $\mathrm{Al}_{2} \mathrm{O}_{3}$ ) from the glass field is a measure of the extent of post-trapping modification. A simple calculation demonstrates that the least magnesian inclusion $(\mathrm{MgO} \approx$ $4 \mathrm{wt} \%)$ and the most magnesian inclusion ( $\mathrm{MgO} \sim 16 \mathrm{wt} \%)$ are produced by post-trapping crystallization of $\sim 15 \mathrm{wt} \%$ olivine and $\sim 45$ $\mathrm{wt} \%$ plagioclase, respectively.

Whereas post-trapping modification does not significantly affect $\mathrm{Na}_{2} \mathrm{O}$ contents of inclusions we analyzed in olivine, it has a dramatic effect on the $\mathrm{Na}_{2} \mathrm{O}$ content of inclusions in plagioclase (Fig. 6B) and thus $\mathrm{CaO} / \mathrm{Na}_{2} \mathrm{O}$ values (Fig. $6 \mathrm{C}$ ). When only the least modified inclusions (i.e., those with $\mathrm{MgO}$ similar to the pillow-rim glasses) are considered, the range of $\mathrm{CaO} / \mathrm{Na}_{2} \mathrm{O}$ values in inclusions in plagioclase is approximately twice that shown by the pillow glasses (Fig. 6D). Inclusions in plagioclase from Group 1 samples have $\mathrm{CaO} / \mathrm{Na}_{2} \mathrm{O}$ values that cover the entire range. However, inclusions in plagioclase from
Group 2 have low $\mathrm{CaO} / \mathrm{Na}_{2} \mathrm{O}$ values, and inclusions from Group 3 have relatively high $\mathrm{CaO} / \mathrm{Na}_{2} \mathrm{O}$ values when compared with Group 1 glasses. Also, inclusions in olivine (all from Group 3) have $\mathrm{CaO} /$ $\mathrm{Na}_{2} \mathrm{O}$ values that are similar to inclusions in plagioclase from the same group.

There is a remarkable difference in the range of $\mathrm{TiO}_{2}$ contents between inclusions in olivine and plagioclase (Fig. 6E). The range in olivine is the same as that in the glasses, whereas inclusions in plagioclase show large variations in $\mathrm{TiO}_{2}$ content that are independent both of the degree of post-trapping modification and of the sample group. Inclusions in both olivine and plagioclase show a wide range of $\mathrm{K}_{2} \mathrm{O}$ contents, several times that of the pillow-rim glasses (Fig. $6 \mathrm{~F})$, that are also independent both of the degree of post-trapping modification and of the glass group. Inclusions with least modified compositions (i.e., those with $\mathrm{MgO}$ similar to the glasses) are shown 


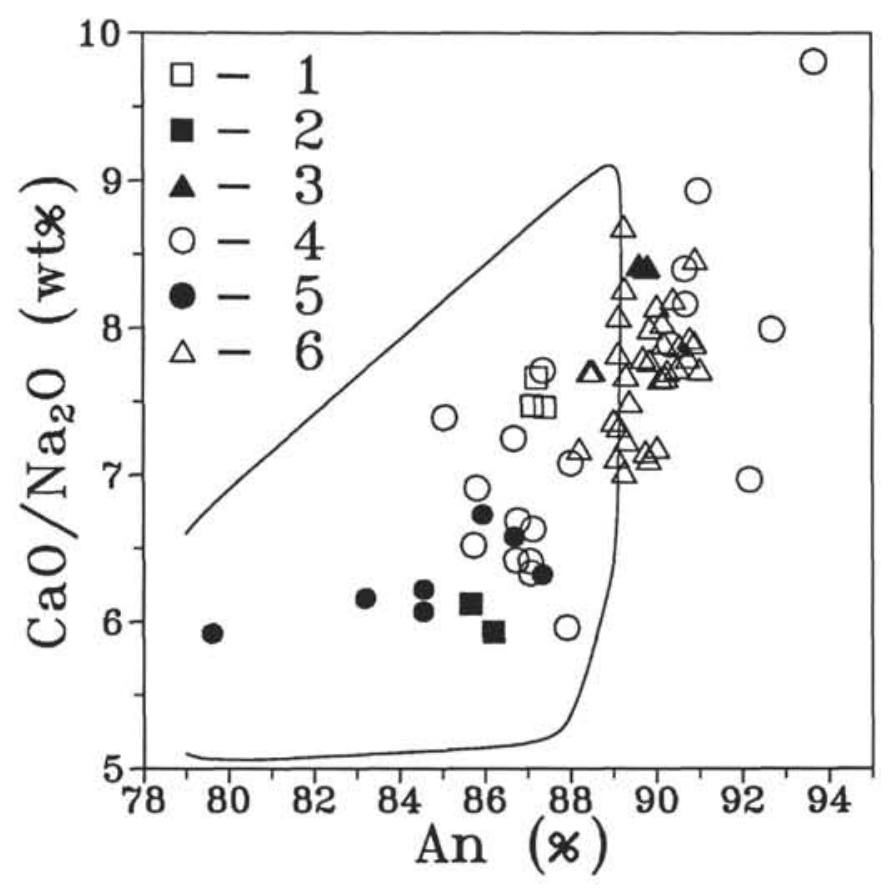

Figure 4. Correlation of plagioclase phenocryst An contents and $\mathrm{CaO} / \mathrm{Na}_{2} \mathrm{O}$ values of equilibrium melts for melt inclusions and pillow-rim glasses. 1 to 3 $=$ Group 1 to 3 glasses, respectively (symbols are the same as on Fig. 2), 4 to $6=$ experimentally reheated inclusions in plagioclase from Groups 1 to 3 , respectively. For comparison the field of 1 -atm experiments on MORB compositions is also shown (data from Bender et al., 1978; Duncan and Green, 1987; Gaetani et al., 1994; Grove and Bryan, 1983; Grove et al., 1982; and Walker et al.. 1979).

separately on Figure 7. Variations in $\mathrm{K}_{2} \mathrm{O}, \mathrm{TiO}_{2}$ and, $\mathrm{Na}_{2} \mathrm{O}$ content of these inclusions are not related to each other or to the glass group. However, we note that all our analyzed high $\mathrm{K}_{2} \mathrm{O}$ inclusions have high $\mathrm{Na}_{2} \mathrm{O}$ contents, although low $\mathrm{K}_{2} \mathrm{O}$ inclusions with high $\mathrm{Na}_{2} \mathrm{O}$ content also exist. Inclusions in spinel do not show any unusual compositional features and are not shown on these plots as they overlap with the pillow-rim glasses.

In summary, the compositions of naturally quenched inclusions have a much wider range than the pillow-rim glasses, and inclusions in plagioclase show much more compositional scatter than those in olivine and spinel. We emphasize the large variation in $\mathrm{TiO}_{2}$ contents of inclusions in plagioclase, which is not seen in inclusions from olivine and spinel and the pillow-rim glasses. In addition, some inclusions in both olivine and plagioclase are characterized by unusually high $\mathrm{K}_{2} \mathrm{O}$ contents. Inclusions in plagioclase interpreted to have undergone significant post-trapping modification are characterized by severe $\mathrm{Na}_{2} \mathrm{O}$ depletion and subsequent increase in $\mathrm{CaO} / \mathrm{Na}_{2} \mathrm{O}$ values. The low $\mathrm{Na}_{2} \mathrm{O}$ and high $\mathrm{CaO} / \mathrm{Na}_{2} \mathrm{O}$ that are characteristic of many naturally quenched inclusions in plagioclase are not matched by compositions of inclusions in olivine and spinel or compositions of the pillow-rim glasses. A thorough analysis of these features is beyond the scope of this paper, however we note that the results presented above highlight the danger of using even incompatible element ratios from naturally quenched inclusions in plagioclase as petrogenetic indicators.

\section{Fluid Inclusions}

Fluid inclusions were found in plagioclase phenocrysts and indicate that the melt was fluid saturated during plagioclase crystallization. However, no fluid inclusions were found in olivine phenocrysts.

\section{Experimental Results}

\section{Plagioclase}

Inclusions of 10-30 $\mu \mathrm{m}$ diameter were found to be the most useful for experiments, as most inclusions $>30 \mu \mathrm{m}$ diameter leaked during reheating (indicated by increased bubble size and $T_{h}$ ), whereas those of $<10 \mu \mathrm{m}$ diameter were too small to easily observe the homogenization process. All inclusions used for experiments were glassy, with no obvious daughter crystals at room temperature.

On heating to $600^{\circ}-800^{\circ} \mathrm{C}$, the inclusions darkened as daughter crystals formed and bubbles appeared (if none were present initially). In some grains, considerable fracturing was observed at temperatures of $>400^{\circ}$ to $600^{\circ} \mathrm{C}$. With increasing temperature, generally at $>1150^{\circ} \mathrm{C}$, the color of the inclusions became lighter again, as the daughter crystals started melting. Closer to $T_{h}$, at $>1190^{\circ} \mathrm{C}$, most silicate daughter crystals within the volume of the inclusion had melted, leaving a fluid bubble, and in many experiments a small, black, $\sim 2$ to $3-\mu \mathrm{m}$ diameter, $\mathrm{Fe}-\mathrm{Cu}-\mathrm{Ni}$ sulfide globule (identified using EDS on the microprobe). These sulfides often coalesced with the fluid bubble at temperatures close to $T_{h}$, making accurate determination of the exact temperature of bubble disappearance difficult. In large inclusions, the daughter crystals often recrystallized to a single olivine of $\sim 2 \mu \mathrm{m}$ diameter that could not be remelted in the time available. On quenching a successful run, most small $(<15 \mu \mathrm{m}$ diameter) inclusions remained glassy, with no bubble; however larger inclusions often had a vapor bubble indicating that they were not homogenized.

As the melt has been demonstrated to be fluid-saturated during plagioclase crystallization, then $T_{h}$, which corresponded to the disappearance of the fluid bubble, should equal the trapping temperature (Sobolev and Danyushevsky, 1994). Homogenization was achieved in 40 runs; 118 inclusions were analyzed from these runs. Homogenization temperatures ranged from $1195^{\circ}$ to $1225^{\circ} \mathrm{C}$. Based on these results, no correlation exists between $T_{h}$ and the host plagioclase An content. However, as the range of $T_{h}$ obtained is within the error of the technique used $\left(+15^{\circ} \mathrm{C}\right)$, the existence or otherwise of a correlation between $T_{h}$ and host anorthite cannot be determined.

Compositions of homogenized inclusions are shown on Figure 8. The compositional range of major elements overlaps that of the pillow-rim glasses but shows more scatter. The compositional ranges of minor elements $\left(\mathrm{TiO}_{2}, \mathrm{~K}_{2} \mathrm{O}\right.$, and $\left.\mathrm{Na}_{2} \mathrm{O}\right)$ show significantly more variation, with a similar range to the compositions of least modified naturally quenched inclusions (Fig. 7). As can be seen on Figures 2 and 8 and as discussed in the mineralogical section, the compositional variations of this suite are consistent with cotectic olivine-plagioclase crystallization. As plagioclase phenocrysts are in general in equilibrium with pillow-rim glasses, melt trapped by these plagioclases should be co-saturated with olivine and plagioclase. However, as is obvious from Figure 8, the major element compositions of many inclusions lie off the cotectic as defined by the glasses. Assuming that no chemical exchange occurred between host and inclusion after trapping, then three major processes can affect the composition of an analyzed inclusion. Overheating during the run (homogenization obtained at higher temperature than the temperature of trapping, a function of the kinetics of melting) and/or analytical overlap with the host plagioclase, caused by the uncontrolled thickness (depth) of inclusions being analyzed, will both result in enrichment of the melt in plagioclase components. Poor quenching, particularly common in small inclusions such as those used in this study, will result in depletion of the melt in plagioclase components.

Olivine and plagioclase mineral-melt geothermometers are a useful tool that can reveal inclusion compositions affected by these processes. In this paper, we use a calibration by Danyushevsky et al. (in press), developed to estimate the olivine-plagioclase cotectic, that uses the olivine-melt geothermometer of Ford et al. (1983) and the plagioclase-melt geothermometer of Weaver and Langmuir (1990). A correction has been introduced to the latter to obtain a best fit of the olivine-plagioclase cotectic over the MORB compositional spectrum. Compositions affected by trapping of the host mineral during 
Table 4. Representative olivine analyses, Hole 896A.

\begin{tabular}{|c|c|c|c|c|c|c|c|c|c|c|}
\hline Analysis no: & 1 & 2 & 3 & 4 & 5 & 6 & 7 & 8 & 9 & 10 \\
\hline $\mathrm{SiO}_{2}$ & 40.23 & 40.02 & 40.52 & 40.45 & 40.04 & 40.28 & 40.40 & 40.71 & 38.77 & 39.63 \\
\hline $\mathrm{FeO}^{2}$ & 11.15 & 11.46 & 10.63 & 10.96 & 12.12 & 10.59 & 10.13 & 8.25 & 17.97 & 14.04 \\
\hline $\mathrm{MnO}$ & 0.12 & 0.15 & 0.20 & 0.10 & 0.15 & 0.21 & 0.16 & 0.15 & 0.30 & 0.23 \\
\hline $\mathrm{MgO}$ & 47.55 & 47.58 & 47.80 & 47.68 & 46.84 & 48.60 & 48.58 & 50.16 & 41.94 & 45.64 \\
\hline $\mathrm{CaO}$ & 0.33 & 0.35 & 0.30 & 0.32 & 0.55 & 0.32 & 0.34 & 0.32 & 0.23 & 0.30 \\
\hline $\mathrm{Cr}_{2} \mathrm{O}_{3}$ & 0.06 & 0.07 & 0.04 & 0.06 & 0.36 & 0.03 & 0.04 & 0.06 & 0.03 & 0.04 \\
\hline $\mathrm{NiŌ}$ & 0.26 & 0.26 & 0.28 & 0.26 & 0.20 & 0.27 & 0.21 & 0.26 & 0.17 & 0.23 \\
\hline Total & 99.70 & 99.89 & 99.77 & 99.83 & 100.26 & 100.30 & 99.86 & 99.91 & 99.41 & 100.11 \\
\hline \multicolumn{11}{|c|}{ Cations calculated on the basis of 4 oxygens } \\
\hline $\mathrm{Si}$ & 0.997 & 0.992 & 1.001 & 1.000 & 0.993 & 0.991 & 0.995 & 0.994 & 0.996 & 0.992 \\
\hline $\mathrm{Fe}$ & 0.231 & 0.238 & 0.220 & 0.227 & 0.251 & 0.218 & 0.209 & 0.168 & 0.386 & 0.294 \\
\hline $\mathrm{Mg}$ & 1.757 & 1.758 & 1.760 & 1.757 & 1.731 & 1.782 & 1.784 & 1.826 & 1.606 & 1.703 \\
\hline $\mathrm{Ca}$ & 0.009 & 0.009 & 0.008 & 0.008 & 0.015 & 0.008 & 0.009 & 0.008 & 0.006 & 0.008 \\
\hline $\mathrm{Mn}$ & 0.003 & 0.003 & 0.004 & 0.002 & 0.003 & 0.004 & 0.003 & 0.003 & 0.007 & 0.005 \\
\hline $\mathrm{Cr}$ & 0.001 & 0.001 & 0.001 & 0.001 & 0.007 & 0.001 & 0.001 & 0.001 & 0.001 & 0.001 \\
\hline $\mathrm{Ni}$ & 0.005 & 0.005 & 0.006 & 0.005 & 0.004 & 0.005 & 0.004 & 0.005 & 0.004 & 0.005 \\
\hline Total & 3.002 & 3.007 & 2.999 & 3.000 & 3.004 & 3.009 & 3.005 & 3.006 & 3.004 & 3.008 \\
\hline Fo & 88.3 & 88.1 & 88.9 & 88.6 & 87.3 & 89.1 & 89.5 & 91.6 & 80.6 & 85.3 \\
\hline
\end{tabular}

Notes: Alphanumeric codes following sample numbers are identifiers of grain mount and grain number. $1=$ Sample $148-896 \mathrm{~A}-27 \mathrm{R}-1$ (Piece 15 ), A13-88 (hosts plagioclase 12 and 13. Table 3). 2 = Sample 148-896A-27R-I (Piece 15), AI3-141 (hosts melt inclusion 7, Table 7), $3=$ Sample 148-896A-3R-1 (Piece 4), Al4-10 (hosts melt inclusion 6. Table 7), 4= Sample 148-896A-27R-I (Piece 13), A10-40 (hosts melt inclusion 8, Table 7). $5=$ Sample 148-896A-25R-2 (Piece I1), A15-82 (hosts spinel 5. Table 5). 6 = Sample 148-896A9R-1 (Piece 24), A9-6 (hosts spinel 6. Table 5). 7 = Sample 148-896A-25R-1 (Piece 11). A8-5. $8=$ Sample 148-896A-25R-I (Piece II), A8-8. 9= Sample 148-896A-25R-1 (Piece 1I), A8-3, $10=$ Sample 148-896A-9R-1 (Piece 24). A9-42.

Table 5. Representative spinel analyses, Hole 896A.

\begin{tabular}{|c|c|c|c|c|c|c|c|c|c|}
\hline Analysis no:: & 1 & 2 & 3 & 4 & 5 & 6 & 7 & 8 & 9 \\
\hline $\mathrm{SiO}_{2}$ & 0.08 & 0.13 & 0.07 & 0.09 & 0.16 & 0.03 & 0.11 & 0.08 & 0.08 \\
\hline $\mathrm{TiO}_{2}^{2}$ & 0.45 & 0.19 & 0.20 & 0.21 & 0.57 & 0.84 & 0.21 & 0.30 & 0.28 \\
\hline $\mathrm{Al}_{2} \mathrm{O}_{3}$ & 25.6 & 37.22 & 34.85 & 35.64 & 24.96 & 14.35 & 39.73 & 37.58 & 23.03 \\
\hline $\mathrm{Fe}_{2} \mathrm{O}_{3}$ & 6.77 & 5.99 & 5.64 & 5.37 & 6.57 & 14.08 & 5.42 & 5.59 & 5.87 \\
\hline $\mathrm{FeO}$ & 14.93 & 10.51 & 11.02 & 9.96 & 12.42 & 18.99 & 10.12 & 10.57 & 12.80 \\
\hline $\mathrm{MnO}$ & 0.16 & 0.05 & 0.14 & 0.11 & 0.15 & 0.19 & 0.14 & 0.13 & 0.20 \\
\hline $\mathrm{MgO}$ & 13.91 & 18.00 & 17.08 & 17.98 & 15.49 & 9.99 & 18.74 & 18.02 & 15.07 \\
\hline $\mathrm{Cr}_{2} \mathrm{O}_{3}$ & 38.32 & 28.31 & 30.09 & 30.27 & 38.80 & 40.55 & 27.18 & 28.30 & 43.32 \\
\hline $\mathrm{NiŌ}$ & 0.24 & 0.24 & 0.19 & 0.19 & 0.08 & 0.11 & 0.23 & 0.20 & 0.15 \\
\hline $\mathrm{ZnO}$ & 0.09 & 0.09 & 0.06 & 0.14 & 0.03 & 0.12 & 0.04 & 0,10 & 0.03 \\
\hline Total & 100.55 & 100.74 & 99.35 & 99.96 & 99.23 & 99.25 & 101.91 & 100.87 & 100.83 \\
\hline \multicolumn{10}{|c|}{ Cations calculated on the basis of 32 oxygens } \\
\hline $\mathrm{Si}$ & 0.019 & 0.029 & 0.016 & 0.020 & 0.039 & 0.008 & 0.024 & 0.018 & 0.019 \\
\hline $\mathrm{Ti}$ & 0.082 & 0.032 & 0.035 & 0.036 & 0.104 & 0.166 & 0.035 & 0.050 & 0.051 \\
\hline $\mathrm{Al}$ & 7.270 & 9.843 & 9.449 & 9.537 & 7.109 & 4.444 & 10.273 & 9.913 & 6.542 \\
\hline $\mathrm{Fe}_{2+}^{3+}$ & 1.227 & 1.013 & 0.977 & 0.917 & 1.194 & 2.785 & 0.894 & 0.942 & 1.064 \\
\hline $\mathrm{Fe}^{2+}$ & 3.009 & 1.973 & 2.121 & 1.891 & 2.510 & 4.172 & 1.856 & 1.978 & 2.580 \\
\hline $\mathrm{Mn}$ & 0.033 & 0.010 & 0.027 & 0.021 & 0.031 & 0.042 & 0.026 & 0.025 & 0.041 \\
\hline $\mathrm{Mg}$ & 4.997 & 6.021 & 5.858 & 6.086 & 5.580 & 3.913 & 6.129 & 6.013 & 5.414 \\
\hline $\mathrm{Cr}$ & 7.301 & 5.022 & 5.473 & 5.434 & 7.413 & 8.424 & 4.715 & 5.008 & 8.255 \\
\hline $\mathrm{Ni}$ & 0.047 & 0.043 & 0.035 & 0.035 & 0.016 & 0.023 & 0.041 & 0.036 & 0.029 \\
\hline $\mathrm{Zn}$ & 0.016 & 0.015 & 0.010 & 0.023 & 0.005 & 0.023 & 0.006 & 0.017 & 0.005 \\
\hline $\mathrm{Mg}^{\prime}$ & 62.4 & 75.3 & 73.4 & 76.3 & 69.0 & 48.4 & 76.8 & 75.2 & 67.7 \\
\hline $\mathrm{Cr} \#$ & 50.1 & 33.8 & 36.7 & 36.3 & 51.0 & 65.5 & 31.5 & 33.6 & 55.8 \\
\hline
\end{tabular}

Notes: Alphanumeric codes following sample numbers are identifiers of grain mount and grain number. $\mathrm{Fe}_{2} \mathrm{O}_{3}$ calculated assuming stoichiometry. $\mathrm{I}=\mathrm{Sample} 148-896 \mathrm{~A}-4 \mathrm{R}-1$ (Piece 2), T-2 (inclusion in plagioclase 10, Table 3), 2 =Sample 148-896A-4R-I (Piece 2), T-5 (inclusion in plagioclase II, Table 3), $3=$ Sample I48-896A-27R-I (Piece 15). AI3-93 (inclusion in plagioclase 9. Table 3). 4= Sample 148-896A-27R-1 (Piece 15), A13-133 (inclusion in plagioclase 8, Table 3). 5= Sample 148-896A-25R-2 (Piece 11), A15-82 (inclusion in olivine 5. Table 4), 6 = Sample 148-896A-9R-1 (Piece 24), A9-6 (inclusion in olivine 6. Table 4). 7= Sample 148-896A-25R-1 (Piece 11), A.3-57 (hosts glass inclusion 9. Table 7). $8=$ Sample 148-896A-25R-1 (Piece 11), A3-2, $9=$ Sample 148-896A-27R-1 (Piece 15$), \mathrm{A}_{12}-1 . \mathrm{Mg}^{\prime}=100 \times\left[\mathrm{Mg} /\left(\mathrm{Mg}+\mathrm{Fe}^{2+}\right)\right]$.

analysis are identified by calculated plagioclase temperatures higher than the run temperature, whereas poor quenching will yield lower calculated temperatures (Fig. 9A). Comparison of olivine- and plagioclase-calculated temperatures can reveal inclusion compositions that are the result of overheating or poor quenching (Fig. 9B).

Sixty-three inclusions from 29 runs were found to satisfy the criteria discussed above. Their $T_{l,}$ and compositions are given in Table 8 and are compared with pillow-rim glasses on Figure 10. The remaining inclusions have a more restricted major element compositional range, consistent with olivine-plagioclase cotectic crystallization, but they still show wide variations in minor element contents. Good correlation exists between $\mathrm{CaO} / \mathrm{Na}_{2} \mathrm{O}$ values of inclusions and host $\mathrm{An}$ contents (Fig. 4), consistent with low-pressure experimental results on plagioclase-melt equilibria and with plagioclase-host glass relationships. This indicates that the compositions of homogenized inclusions are in equilibrium with host plagioclases. As with the leastmodified naturally quenched inclusions (Fig. 6D), homogenized inclusions from different groups vary consistently in $\mathrm{CaO} / \mathrm{Na}_{2} \mathrm{O}$; inclusions from Group 1 span the range of observed $\mathrm{CaO} / \mathrm{Na}_{2} \mathrm{O}$ values. The ranges in $\mathrm{CaO} / \mathrm{Na}_{2} \mathrm{O}$ of homogenized inclusions appear to be slightly smaller than those of naturally quenched inclusions, but this may be related to sampling. In both cases, $\mathrm{CaO} / \mathrm{Na}_{2} \mathrm{O}$ values higher than those in the pillow-rim glasses were found. The trend of $\mathrm{Al}_{2} \mathrm{O}_{3}$ and $\mathrm{CaO}$ vs. $\mathrm{MgO}$ defined by inclusions is the same as those of glasses; however, it appears that inclusions have higher $\mathrm{SiO}_{2}$ and lower $\mathrm{FeO}$ contents at the same $\mathrm{MgO}$ than the glasses. Higher $\mathrm{SiO}_{2}$ contents 

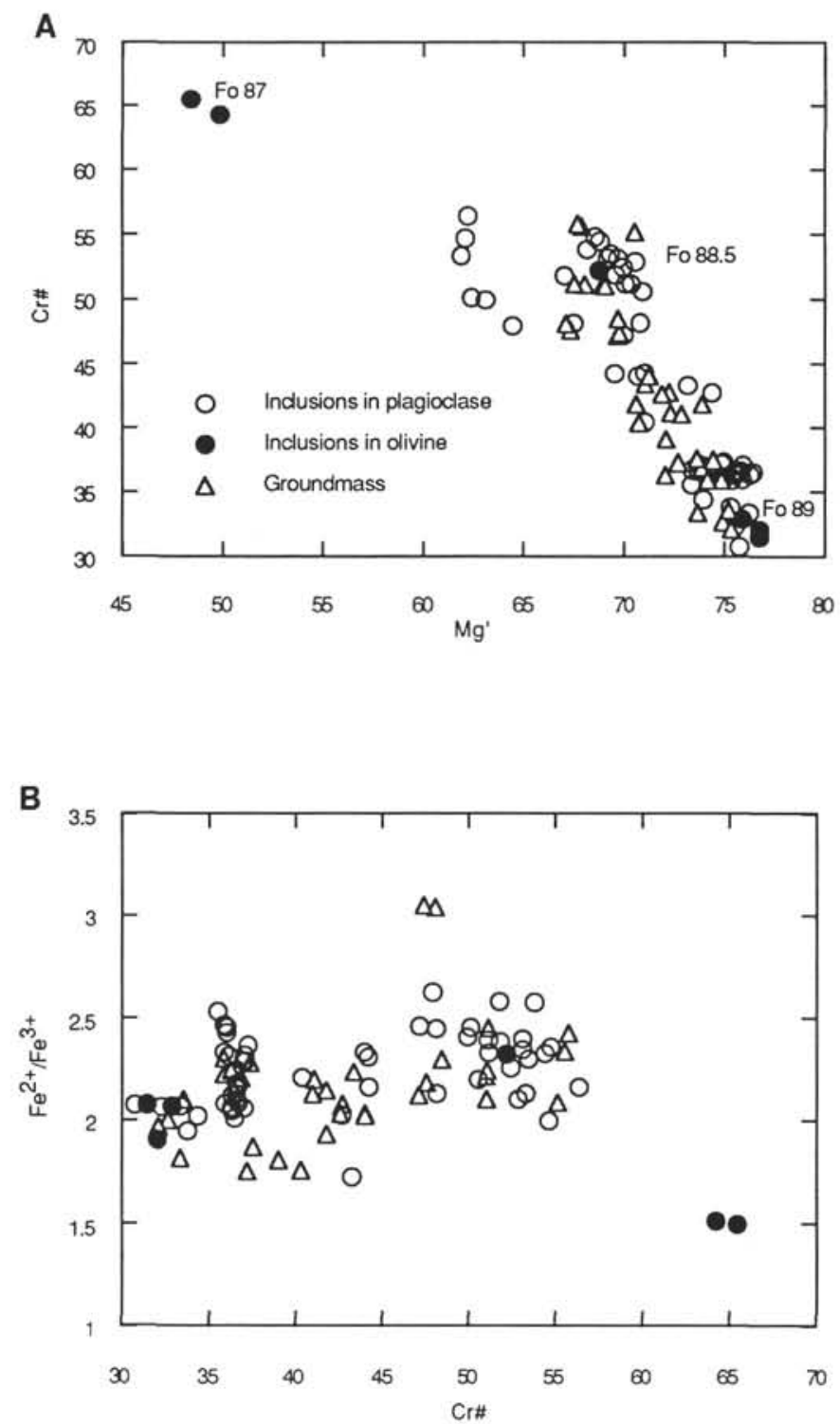

Figure 5. Compositional variation of spinels. A. $\mathrm{Cr} \#([00 \times \mathrm{Cr} /[\mathrm{Cr}+\mathrm{Al}]) \mathrm{vs}$. $\mathrm{Mg}^{\prime}\left(100 \times \mathrm{Mg} /\left[\mathrm{Mg}+\mathrm{Fe}^{2+}\right]\right)$ for groundmass spinels and spinels included in olivine (Fo contents as indicated) and plagioclase. B. Calculated $\mathrm{Fe}^{2+} / \mathrm{Fe}^{3+}$ vs. Cr\# for all spinels.

were also observed in the least-modified naturally quenched inclusions.

\section{Olivine}

Inclusions of $<100 \mu \mathrm{m}$ diameter were selected for experiments as it was found that larger inclusions often leaked during heating. A slower heating rate was initially required than for plagioclase to nucleate a fluid bubble at $750^{\circ}-900^{\circ} \mathrm{C}$, and recrystallization of the inclusion occurred from $1000^{\circ}$ to $1080^{\circ} \mathrm{C}$; melting began at $\sim 1130^{\circ} \mathrm{C}$. Unlike inclusions in plagioclase, homogenization could be achieved after keeping inclusions at a constant temperature for more than 10 min, indicating slower melting kinetics in inclusions in olivine. For example, after homogenization of the smaller $20-40 \mu \mathrm{m}$ inclusions, up to $20 \mathrm{~min}$ was required to homogenize larger inclusions. After 2 $3 \mathrm{~min}$ at $T_{h}$, small $(<1 \mu \mathrm{m}$ ) black minerals (most likely magnetite, the result of oxidation; Sobolev and Danyushevsky, 1994) crystallized in all inclusions, although the relative amount varied from inclusion to
Table 6. Representative clinopyroxene analyses, Hole 896A.

\begin{tabular}{|c|c|c|c|c|c|}
\hline Analysis no.: & 1 & 2 & 3 & 4 & 5 \\
\hline $\mathrm{SiO}_{2}$ & 53.97 & 50.60 & 46.04 & 50.49 & 51.63 \\
\hline $\mathrm{TiO}_{2}^{-}$ & 0.17 & 0.56 & 1.42 & 0.60 & 0.30 \\
\hline $\mathrm{Al}_{2} \mathrm{O}_{3}$ & 1.51 & 4.48 & 8.64 & 4.74 & 3.16 \\
\hline $\mathrm{FeO}$ & 3.19 & 6.03 & 8.98 & 6.40 & 4.56 \\
\hline $\mathrm{MnO}$ & 0.08 & 0.15 & 0.16 & 0.18 & 0.08 \\
\hline $\mathrm{MgO}$ & 17.77 & 15.33 & 12.22 & 15.18 & 16.39 \\
\hline $\mathrm{CaO}$ & 22.89 & 22.37 & 21.68 & 21.98 & 22.45 \\
\hline $\mathrm{Na}_{2} \mathrm{O}$ & 0.11 & 0.22 & 0.37 & 0.18 & 0.17 \\
\hline $\mathrm{Cr}_{2} \mathrm{O}_{3}$ & 0.42 & 0.44 & 0.04 & 0.21 & 0.86 \\
\hline Total & 100.11 & 100.18 & 99.55 & 99.96 & 99.60 \\
\hline \multicolumn{6}{|c|}{ Cations calculated on the basis of 6 oxygens } \\
\hline $\mathrm{Si}$ & 1.960 & 1.866 & 1.737 & 1.866 & 1.902 \\
\hline $\mathrm{Ti}$ & 0.005 & 0.016 & 0.040 & 0.017 & 0.008 \\
\hline Al & 0.065 & 0.195 & 0.384 & 0.206 & 0.137 \\
\hline $\mathrm{Fe}$ & 0.097 & 0.186 & 0.283 & 0.198 & 0.141 \\
\hline $\mathrm{Mn}$ & 0.002 & 0.005 & 0.005 & 0.006 & 0.002 \\
\hline $\mathrm{Mg}$ & 0.962 & 0.843 & 0.688 & 0.836 & 0.900 \\
\hline $\mathrm{Ca}$ & 0.891 & 0.884 & 0.877 & 0.870 & 0.886 \\
\hline $\mathrm{Na}$ & 0.008 & 0.016 & 0.027 & 0.013 & 0.012 \\
\hline $\mathrm{Cr}$ & 0.012 & 0.013 & 0.001 & 0.006 & 0.025 \\
\hline Total & 4.001 & 4.022 & 4.043 & 4.018 & 4.014 \\
\hline En & 49.3 & 44.1 & 37.3 & 43.9 & 46.7 \\
\hline Fs & 5.0 & 9.7 & 15.3 & 10.4 & 7.3 \\
\hline Wo & 45.7 & 46.2 & 47.4 & 45.7 & 46.0 \\
\hline $\mathrm{Mg \#}$ & 90.9 & 81.9 & 70.8 & 80.9 & 86.5 \\
\hline
\end{tabular}

Notes: Alphanumeric codes following sample numbers are identifiers of grain mount and grain number. 1 = Sample 148-896A-9R-1 (Piece 24), A9-30. 2 = Sample 148896A-27R-1 (Piece 15), Al3-83, 3 = Sample 148-896A-3R-1 (Piece 4), Al4-24, 4 $=$ Sample 148-896A-9R-1 (Piece 24). A9-26. $5=$ Sample 148-896A-27R-1 (Piece 15). A13-67. All Fe as FeO. $\mathrm{Mg} \#=100 \times[\mathrm{Mg} /(\mathrm{Mg}+\mathrm{Fe}) \mid$.

inclusion. On quenching, most inclusions were glassy, with scattered magnetite(?) dust and vapor bubbles in some of the larger inclusions.

Homogenization was achieved in six experiments, with $T_{h}$ ranging from $1190^{\circ}$ to $1200^{\circ} \mathrm{C}$ for host olivines of $\mathrm{Fo}_{87.9-88.7}$. As with plagioclase, no correlation exists between olivine composition and $T_{h}$, probably because of the very narrow range of experimental temperatures and olivine compositions. Temperatures of olivine saturation calculated from inclusion compositions, using the calibration of Ford et al. (1983), agree well with experimental temperatures (Fig. I1), indicating that equilibrium was obtained during the runs and that no significant quench modification occurred. Compositions of homogenized inclusions are shown on Figure 12. Contrary to the mineralogical evidence, which suggested that olivines of $\sim \mathrm{Fo}_{88}$ should be in equilibrium with more magnesian melts than the host glasses, the $\mathrm{MgO}$ contents of homogenized inclusions are significantly lower than those of the host glasses. Also $\mathrm{Na}_{2} \mathrm{O}, \mathrm{TiO}_{2}, \mathrm{Al}_{2} \mathrm{O}_{3}$, and $\mathrm{FeO}$ contents of these inclusions differ significantly from the field of pillowrim glasses, a feature not observed in the least-modified naturally quenched inclusions. In addition, the $\mathrm{Mg \# s}$ of these inclusions are far too low to be in equilibrium with their hosts (Table 9). These compositional features may be produced if $T_{h}$ is lower that the trapping temperature. This would be the case for a fluid-undersaturated melt; as no fluid inclusions were found in olivine phenocrysts, we suggest that these inclusions were trapped from such a melt. To obtain the true composition of the trapped melt, more olivine should therefore be added to these inclusion compositions. As magnetite precipitation during the run could introduce additional compositional variations, we estimated the melt composition in equilibrium with olivine phenocrysts by simulating the reverse of olivine crystallization on inclusion walls for the least-modified naturally quenched inclusions. Calculations were performed using the olivine-melt model of Ford et al. $(1983)$ and a melt $\mathrm{Fe}^{2+} / \mathrm{Fe}^{3+}$ of $7.9\left(\mathrm{Fe}^{3+} / \Sigma \mathrm{Fe}=0.112\right)$. This value was obtained from the average spinel $\mathrm{Fe}^{2+} / \mathrm{Fe}^{3+}$ (2.2; from Fig. 5B), using the equation of Maurel and Maurel (1982). Results are shown on Figure 12. Calculated compositions are consistent with their being more primitive melts of the same suite as the host glasses, with calculated equilibrium temperatures of $1240^{\circ}-1260^{\circ} \mathrm{C}$. 
Table 7. Representative analyses of naturally quenched melt inclusions, Hole 896A.

\begin{tabular}{|c|c|c|c|c|c|c|c|c|c|}
\hline \multirow[b]{2}{*}{ Analysis no.: } & \multicolumn{5}{|c|}{ Plagioclase } & \multicolumn{3}{|c|}{ Olivine } & \multirow{2}{*}{$\begin{array}{c}\text { Spinel } \\
9\end{array}$} \\
\hline & 1 & 2 & 3 & 4 & 5 & 6 & 7 & 8 & \\
\hline $\mathrm{SiO}_{2}$ & 50.63 & 53.19 & 50.12 & 50.48 & 50.36 & 49.22 & 50.53 & 50.61 & 49.77 \\
\hline $\mathrm{TiO}_{2}^{2}$ & 0.59 & 0.16 & 0.75 & 0.77 & 0.99 & 0.67 & 0.66 & 0.66 & 0.93 \\
\hline $\mathrm{Al}_{2} \mathrm{O}_{3}$ & 8.71 & 9.20 & 12.36 & 15.29 & 15.36 & 18.41 & 17.66 & 18.70 & 16.39 \\
\hline $\mathrm{FeO}$ & 11.90 & 9.34 & 11.04 & 8.69 & 9.89 & 8.79 & 8.87 & 8.01 & 7.11 \\
\hline $\mathrm{MnO}$ & 0.24 & 0.20 & 0.10 & 0.27 & 0.27 & 0.12 & 0.08 & 0.14 & 0.09 \\
\hline $\mathrm{MgO}$ & 13.59 & 13.47 & 12.04 & 9.21 & 7.92 & 6.62 & 5.90 & 3.90 & 9.98 \\
\hline $\mathrm{CaO}$ & 12.77 & 13.88 & 12.73 & 12.36 & 13.11 & 14.59 & 14.74 & 16.26 & 13.24 \\
\hline $\mathrm{Na}_{2} \mathrm{O}$ & 1.12 & 0.72 & 1.44 & 2.25 & 1.87 & 1.78 & 1.71 & 1.65 & 1.88 \\
\hline $\mathrm{K}, \mathrm{O}$ & 0.01 & 0.01 & 0.03 & 0.21 & 0.04 & 0.01 & 0.10 & 0.02 & 0.02 \\
\hline $\mathrm{P}_{2} \mathrm{O}_{5}$ & 0.05 & 0.01 & 0.06 & 0.03 & 0.00 & 0.07 & 0.11 & 0.06 & 0.03 \\
\hline $\mathrm{Cr}_{2} \mathrm{O}_{3}$ & 0.04 & 0.09 & 0.08 & 0.04 & 0.04 & 0.06 & 0.14 & 0.03 & 0.43 \\
\hline Total & 99.65 & 100.27 & 100.75 & 99.60 & 99.85 & 100.34 & 100.50 & 100.04 & 100.59 \\
\hline $\mathrm{Mg \#}$ & 67.2 & 72.1 & 66.2 & 65.5 & 58.9 & 57.4 & 54.4 & 46.6 & 71.6 \\
\hline $\mathrm{CaO} / \mathrm{Na}_{2} \mathrm{O}$ & 11.4 & 19,3 & 8.8 & 5.5 & 7.0 & 8.2 & 8.6 & 9.9 & 7.0 \\
\hline Host & 94.0 & 93.3 & 92.9 & 88.5 & 85.8 & 88.9 & 87.8 & 88.6 & \\
\hline
\end{tabular}

Notes: Alphanumeric codes following sample numbers are identifiers of grain mount and grain number. $1=$ Sample $148-896 \mathrm{~A}-9 \mathrm{R}-1$ (Piece 24 ), A9-54 (hosted by plagiolcase 1. Table 3). 2 = Sample 148-896A-9R-1 (Piece 24). A9-21 (hosted by plagioclase 2, Table 3). 3 = Sample 148-896A-27R-I (Piece 13). A13-116 (hosted by plagioclase 4, Table 3). 4 = Sample 148-896A-9R-1 (Piece 24), 12-15 (hosted by plagioclase 4. Table 3). $5=$ Sample 148-896A-9R-1 (Piece 24). 12-18 (hosted by plagioclase 5, Table 3). $6=$ Sample 148896A-3R-1 (Piece 4), A 14-10 (hosted by olivine 2. Table 4). 7 = Sample 148-896A-27R-1 (Piece 15). A 13-14I (hosted by olivine 3. Table 4). 8= Sample 148-896A-27R-1, Piece 13. A10-40 (hosted by olivine 4. Table 4), 9 = Sample 148-896A-25R-1 (Piece 11), A8-57 (hosted by spinel 7, Table 5). All Fe as FeO. Host mineral composition (host): anorthite $=\mathrm{Ca} /(\mathrm{Ca}+\mathrm{Na})$ and forsterite $=\mathrm{Mg} /(\mathrm{Mg}+\mathrm{Fe})$.

As with inclusions in plagioclase, both homogenized and naturally quenched inclusions in olivine have a larger range and extend to higher $\mathrm{CaO} / \mathrm{Na}_{2} \mathrm{O}$ values than the pillow-rim glasses. However, unlike inclusions in plagioclase, unusually low $\mathrm{TiO}_{2}, \mathrm{FeO}$, and $\mathrm{Na}_{2} \mathrm{O}$ contents have not been found in inclusions in olivine.

\section{DISCUSSION}

Compositions of both homogenized and the least-modified naturally quenched inclusions in plagioclase and olivine have a significantly wider range of $\mathrm{CaO} / \mathrm{Na}_{2} \mathrm{O}$ than the pillow-rim glasses, although there are some correlations with the glass group. All inclusions from Group 2 have lower $\mathrm{CaO} / \mathrm{Na}_{2} \mathrm{O}$ than inclusions from Group 3; however, those from Group I cover the entire range (Figs. $6,10)$. This suggests that magma mixing may have played an important role during the evolution of this suite. Mixing is also suggested by olivine-plagioclase mineralogical relationships, where plagioclases, interpreted to be in equilibrium with host glasses (Fig. 4), are included in olivines that are too magnesian to be in equilibrium with the same glasses, suggesting mixing of primitive and more evolved melts. A detailed examination of evidence for mixing will be presented elsewhere.

Many inclusions in plagioclase and some in olivine have significantly higher $\mathrm{K}_{2} \mathrm{O}$ (up to $0.74 \%$; Figs. 6,10 ) than pillow-rim glasses. Higher $\mathrm{K}_{2} \mathrm{O}$ in plagioclase inclusions has also been reported from the extrusive sequence of Hole 504B (Natland, et al., 1983). The reasons for this are unclear. However, unlike the suggestion of Natland et al. (1983) that they may reflect kinetic effects during trapping, we favor a hypothesis linking high $\mathrm{K}_{2} \mathrm{O}$ content of some inclusions with local contamination by seawater-derived hydrothermal fluids. Investigations of the $\mathrm{H}_{2} \mathrm{O}$ content of inclusions with variable $\mathrm{K}_{2} \mathrm{O}$ content are currently in progress.

Inclusions in plagioclase show wide variations in $\mathrm{TiO}_{2}, \mathrm{SiO}_{2}$, and $\mathrm{FeO}$ contents not seen in the pillow-rim glasses and inclusions in olivine and spinel. The $\mathrm{SiO}_{2}$ contents of inclusions in plagioclase are higher, whereas $\mathrm{FeO}$ and $\mathrm{TiO}_{2}$ contents are lower, in comparison with pillow-rim glasses. The occurrence of these variations only in plagioclase suggest that they may result from some reequilibration with plagioclase after trapping, although the mechanism of this process and why it does not occur in olivine and spinel are not known. The lack of correlation between $\mathrm{Ti}, \mathrm{Fe}, \mathrm{Si}$, and $\mathrm{Na}$ and the independence be- tween the magnitude of their variations and $\mathrm{MgO}$ contents indicate no systematic pattern of these variations and their independence from degree of fractionation. In contrast to some recent studies of melt inclusions in plagioclase from other MORB suites (e.g., Nielsen et al., 1994), which suggest that such variations, particularly in $\mathrm{TiO}_{2}$, preserve primary melt increments before aggregation, we suggest that the evolved nature of these melts and the evidence for mixing presented above, make preservation of such features in these samples unlikely.

Our data suggest that plagioclase $\mathrm{An}_{94}$ crystallized from melts with major element compositions similar to the most magnesian $(\sim 9.5 \% \mathrm{MgO})$ pillow-rim glasses but with higher $\mathrm{CaO} / \mathrm{Na}_{2} \mathrm{O}$ values. It appears that variations in $\mathrm{CaO} / \mathrm{Na}_{2} \mathrm{O}$ values of Group 1 and 3 melts are independent of other element concentrations and mainly reflect variations in $\mathrm{Na}_{2} \mathrm{O}$ content. Thus, differences in composition of highAn plagioclase reflect differences in $\mathrm{CaO} / \mathrm{Na}_{2} \mathrm{O}$ values of equilibrium melts rather than degree of fractionation. Such melts were in equilibrium with olivine $\mathrm{Fo}_{86-87}$, suggesting (especially as olivines of up to $\sim \mathrm{FO}_{89.5}$ were found in all glass groups) that these plagioclases crystallized from relatively evolved melts. This implies that an interval of olivine-only crystallization preceded cotectic olivine-plagioclase crystallization. As our experimental results with inclusions in olivine have been shown to be unreliable due to underheating and magnetite precipitation, these inclusions cannot be used to characterize melt compositions in the olivine-only field. However, compositions of primary melts can be estimated by calculations of the reverse of olivine crystallization from the composition that corresponds to the start of cotectic crystallization. Primary melts for each group can be defined as melts in equilibrium with the most magnesian olivine. Although $\mathrm{Fo}_{91.6}$ was found in Group 2 samples only, we think that the similarity of mineralogical features between all groups indicates that this is a sampling effect. Compositions of primary melts for Groups 1 and 3 were calculated from the compositions of the most primitive glasses from these groups.

Using the Petrolog program (Danyushevsky et al., 1990), olivine was added to the glass compositions until it was in equilibrium with olivine of $\mathrm{FO}_{91.6}$ (the most primitive olivine sampled). Melt $\mathrm{Fe}^{2+} / \mathrm{Fe}^{3+}$, required for this calculation, was found to be 7.9 using calculations as described above. The resultant parental melts are given in Table 10. The range of $\mathrm{CaO} / \mathrm{Na}_{2} \mathrm{O}$ values displayed by inclusions from these two groups, being independent of variations in other elements, should reflect variations in $\mathrm{CaO} / \mathrm{Na}_{2} \mathrm{O}$ values of primary melts for 

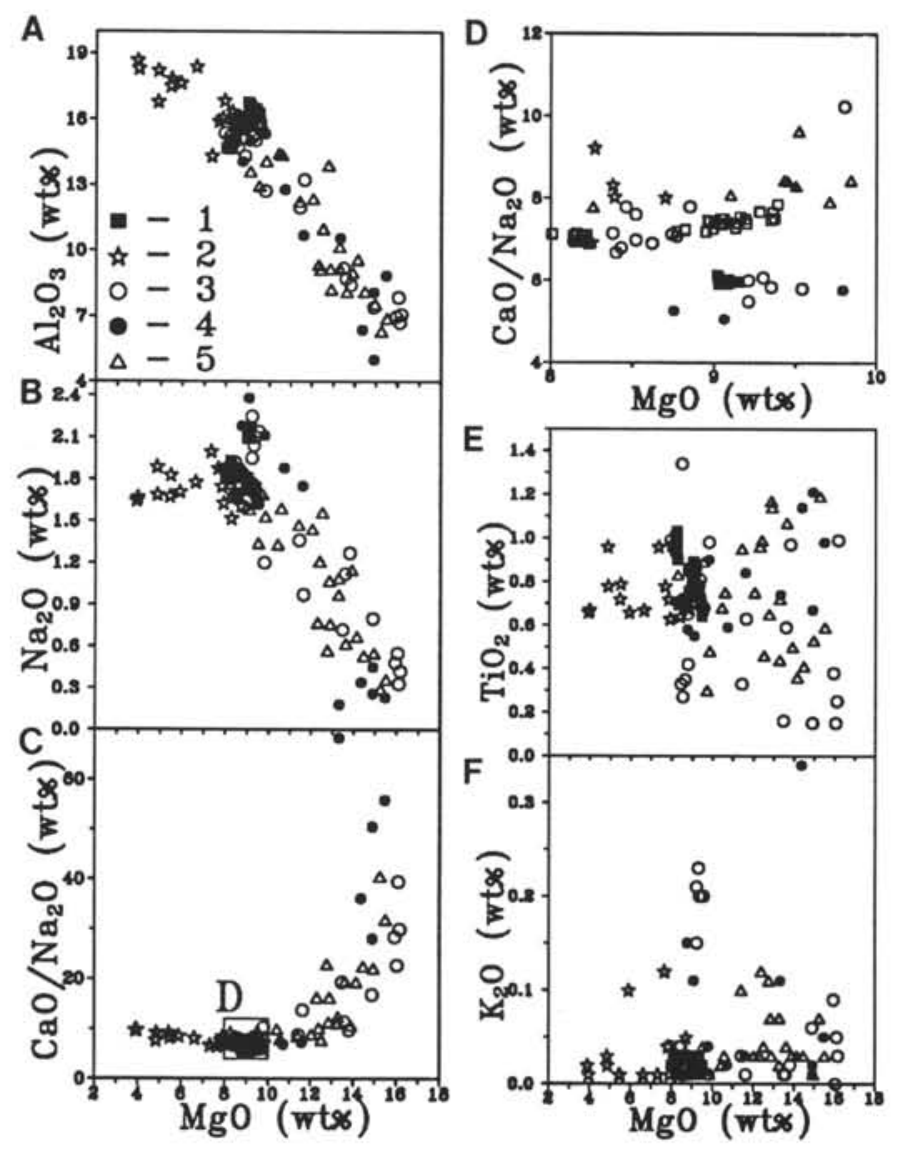

Figure 6. Compositions of naturally quenched melt inclusions in plagioclase and olivine. $\mathrm{MgO}$ vs. $\mathrm{A} . \mathrm{Al}_{2} \mathrm{O}_{3}$, B. $\mathrm{Na}_{2} \mathrm{O}$, and $\mathrm{C}$. $\mathrm{CaO} / \mathrm{Na}_{2} \mathrm{O}$. Variations in $\mathrm{Na}_{2} \mathrm{O}, \mathrm{Al}_{2} \mathrm{O}_{3}$ and $\mathrm{CaO} / \mathrm{Na}_{2} \mathrm{O}$ define trends that are interpreted to reflect differing amounts of post-trapping crystallization. $\mathrm{D}$. $\mathrm{CaO} / \mathrm{Na}_{2} \mathrm{O}$ vs. $\mathrm{MgO}$, for least modified inclusions (i.e., those with $\mathrm{MgO}$ similar to that of the pillowrim glasses). $\mathrm{MgO}$ vs. $\mathbf{E} \cdot \mathrm{TiO}_{2}$ and $\mathbf{F} \cdot \mathrm{K}_{2} \mathrm{O} \cdot \mathrm{TiO}_{2}$ in plagioclase, and $\mathrm{K}_{2} \mathrm{O}$ in both plagioclase and olivine, have a much wider range in the naturally quenched inclusions than in the pillow-rim glasses. Symbols are defined as follows: 1 = pillow-rim glasses; 2 = inclusions in olivine; 3,4 , and 5 = inclusions in plagioclase hosted by Group 1, 2, and 3 glasses, respectively. Pillowrim glasses on Figure 6D are subdivided using symbols as on Figure 2.

each group. For Group 1, this range is 6.9 to 7.9 ; for Group 3, the range is from 8.3 to 8.4 . We have no evidence, however, to suggest that other elements varied in primary melts for these two groups. Glasses from Group 2 are more evolved, making calculations of the primary melt for this group impossible. However, as $\mathrm{Mg}$-Fe covariations of these glasses are indistinguishable from those of Group 1, we think that the primary melt for this group had similar $\mathrm{MgO}$ to Group 1 but lower $\mathrm{CaO} / \mathrm{Na}_{2} \mathrm{O}$. By comparison with the data of Falloon and Green (1988), the estimated primary melts can be produced by melting MORB mantle sources at $\sim 15$ kbar.

\section{SUMMARY}

Glass samples from pillow rims show systematic compositional variations with depth, particularly in $\mathrm{CaO} / \mathrm{Na}_{2} \mathrm{O}$ and $\mathrm{TiO}_{2}$; however, they generally are characterized by high $\mathrm{CaO}$ and $\mathrm{MgO}$ and low $\mathrm{Na}_{2} \mathrm{O}$ and $\mathrm{TiO}_{2}$, when compared with glasses from nearby Hole 504B (Nat-
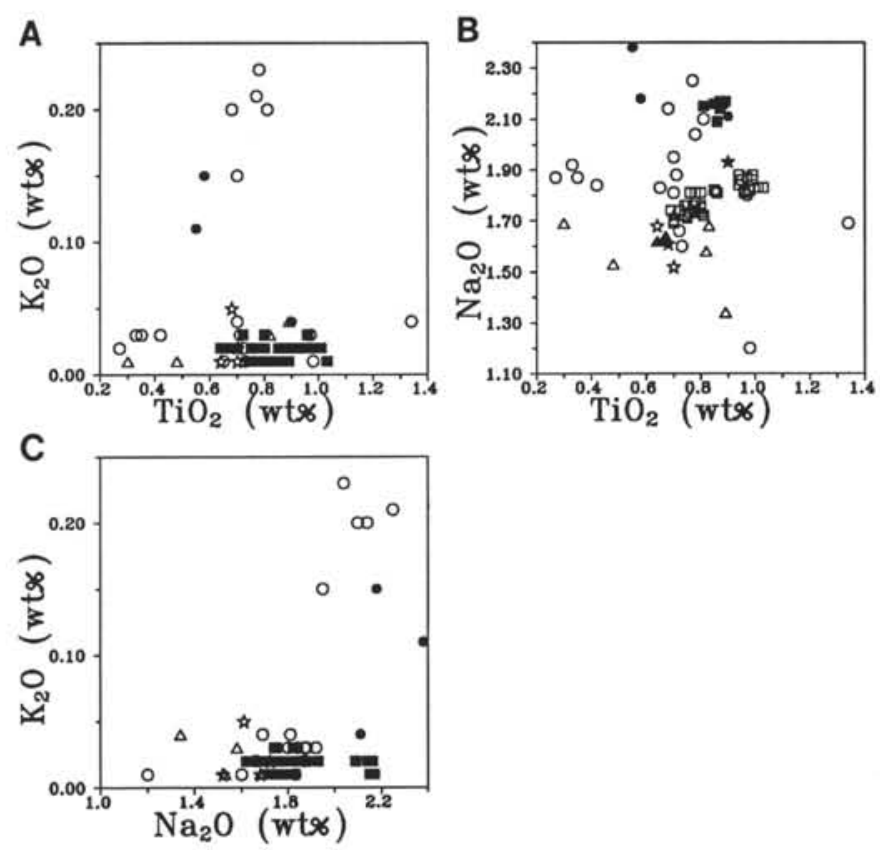

Figure 7. $\mathrm{TiO}_{2}$ vs. variations in $\mathrm{A} . \mathrm{K}_{2} \mathrm{O}$ and $\mathbf{B}$. $\mathrm{Na}_{2} \mathrm{O}$. C. Variations in $\mathrm{K}_{2} \mathrm{O}$ vs. $\mathrm{Na}_{2} \mathrm{O}$ for naturally quenched inclusions in plagioclase and olivine, and pillow-rim glasses. Symbols as on Figure 6D.

land et al., 1983). Water contents $(<0.1 \%)$ are consistent with other MORB suites of similar $\mathrm{Mg} \#$ and $\mathrm{K}_{2} \mathrm{O}$. Seven samples were selected for detailed mineralogical and melt inclusion studies on the basis of these major element variations.

The phenocryst assemblages of the selected samples are dominated by plagioclase $\mathrm{An}_{78-94.5}$, with lesser olivine $\mathrm{Fo}_{80-91.6}, \mathrm{Cr}-\mathrm{Al}$ spinel, and clinopyroxene $(\mathrm{Mg \#}=85-91)$. A correlation between plagioclase composition and pillow-rim glass $\mathrm{CaO} / \mathrm{Na}_{2} \mathrm{O}$ is interpreted to indicate their equilibrium. Textural and chemical correlations between major phenocryst phases and glasses suggest that the most common olivine compositions $\left(\mathrm{Fo}_{87-89}\right)$ crystallized from more primitive melts than recorded in the pillow-rim glasses.

Heating-stage experiments indicate trapping temperatures of $1195^{\circ}-1215^{\circ} \mathrm{C}$ for melt inclusions in plagioclase phenocrysts of $\mathrm{An}_{83-945}$. The compositions of these inclusions are comparable to those of the host glasses, with the exception of anomalous $\mathrm{TiO}_{2}$ and $\mathrm{K}_{2} \mathrm{O}$, and inclusion compositions more primitive than the most magnesian glass $(\mathrm{MgO}=9.5 \%)$ were not found.

The $\mathrm{CaO} / \mathrm{Na}_{2} \mathrm{O}$ of melt inclusions hosted by plagioclase of $\sim \mathrm{An}_{94}$ is $\sim 9.5$, which is considerably lower than the value required by current experimental data to crystallize plagioclase of $>\mathrm{An}_{90}$ (i.e., $\mathrm{CaO} /$ $\mathrm{Na}_{2} \mathrm{O}>10$ ).

Crystallization of plagioclase $\mathrm{An}_{94}$ occurred from relatively evolved melts, the result of $\sim 15 \%$ olivine-only fractionation. Primary melts for this suite had $\mathrm{MgO} \approx 15 \mathrm{wt} \%$; these melts are characterized by variable $\mathrm{CaO} / \mathrm{Na}_{2} \mathrm{O}$ values but relatively constant contents of other elements. Such melts can be produced by melting MORB mantle sources at $\sim 15$ kbar.

\section{ACKNOWLEDGMENTS}

We wish to thank Wieslaw Jablonski, Graham Rowbottom, and Keith Harris for technical assistance. D. Christie and A. Sobolev are also thanked for helpful reviews. The authors were supported by an Australian Research Council fellowship to L.V.D., and an Australian 

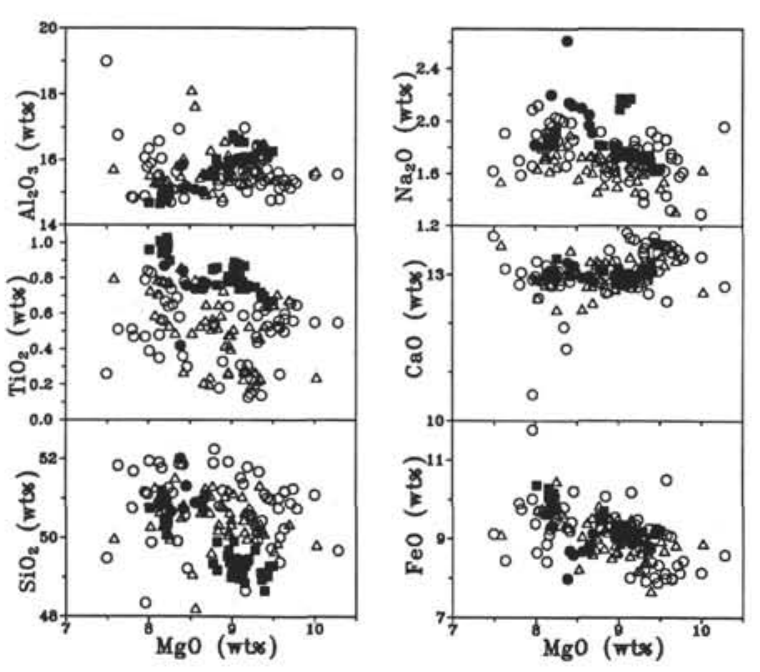

Figure 8. Compositional variations of all experimentally homogenized inclusions in plagioclase. Pillowrim glasses are plotted for comparison. Symbols as for Figure 6A.
A

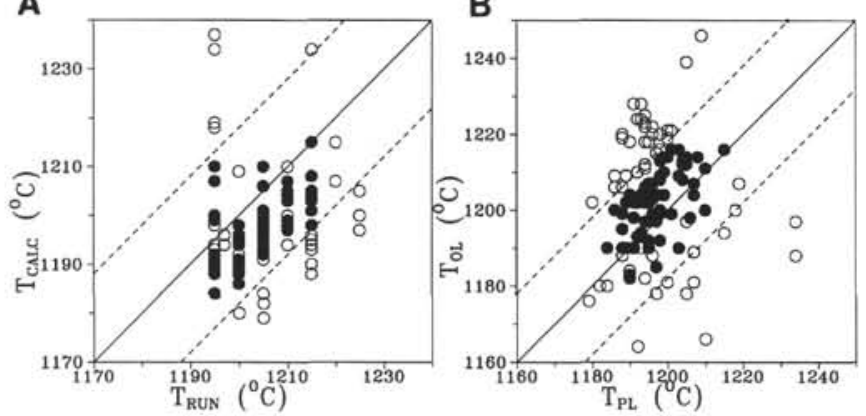

Figure 9. A. Calculated plagioclase temperatures (using the modified plagioclase-melt geothermometer of Weaver and Langmuir, 1990) vs. run temperature for experimentally homogenized inclusions in plagioclase. B. Calculated olivine temperature (using the geothermometer of Ford et al., 1983) vs. calculated plagioclase temperature for all homogenized inclusions in plagioclase. Solid symbols represent inclusions thought to be representative of trapped melt compositions. $\mathrm{T}_{\mathrm{CALC}}=$ calculated temperature, $\mathrm{T}_{\mathrm{RUN}}=$ run temperature, $\mathrm{OL}=$ olivine, and $\mathrm{PL}=$ plagioclase. See text for discussion.

postgraduate research award to A.McN. Funding for the research was through an Australian Research Council Large Grant to Dr. A.J. Crawford.

\section{REFERENCES}

Allan, J.F., Sack, R.O., and Batiza, R., 1988. Cr-rich spinels as petrogenetic indicators: MORB-type lavas from the Lamont seamount chain, eastern Pacific. Am. Mineral., 73:741-753.

Anderson, A.T., Jr., 1974. Evidence for a picritic, volatile rich magma beneath Mt. Shasta, California. J. Petrol., 15:243-267.

Aumento, F., Melson, W.G., et al., 1977. Init. Repts. DSDP, 37: Washington (U.S. Govt. Printing Office).

Bender, J.F., Hodges, F.N., and Bence, A.E., 1978. Petrogenesis of basalts from the Project FAMOUS area: experimental study from 0 to $15 \mathrm{kbars}$. Earth Planet. Sci. Lett., 41:277-302.

Byers, C.D., Garcia, M.O., and Muenow, D.W., 1986. Volatiles in basaltic glasses from the East Pacific Rise at $21^{\circ} \mathrm{N}$ : implications for MORB sources and submarine lava flow morphology. Earth Planet. Sci. Lett., 79:9-20.

Christie, D.M., Carmichael, I.S.E., and Langmuir, C.H., 1986. Oxidation states of mid-ocean ridge basalt glasses. Earth Planet. Sci. Lett., 79:397411 .

Clocchiatti, R., 1977. Les liquides silicates pièges dans les cristaux d'olivine, de plagioclase et de pyroxene: prises d'essai du magma. Application à un basalt à affinitie tholeiitque de la ride oceanique émergée d'Asal (T.F.A.I.). C.R. Acad. Sci. Ser. 2, 284:2203-2206.

Danyushevsky, L.V., Chizhov, S., Kuzmin, V., Pugachov, R., and Sobolev, A.V., 1990. Petrolog v.1.01: Moscow (SeLeSoft Co.).

Danyushevsky, L.V., Falloon. T.J., Sobolev, A.V., Crawford, A.J., Carroll, M., and Price, R.C., 1993. The $\mathrm{H}_{2} \mathrm{O}$ content of basalt glasses from Southwest Pacific back-arc basins. Earth Planet. Sci. Lett., 117:347-362.

Danyushevsky, L.V., Sobolev, A.V., and Dmitriev L.V., 1988. Orthopyroxene-bearing low- $\mathrm{Ti}$ tholeiites as a new type of mid-ocean ridge tholeiite. Trans. USSR Acad. Sci., Earth Sci. Sect., 292:102-105.

, in press. Estimation of the pressure of crystallization and $\mathrm{H}_{2} \mathrm{O}$ content of MORB glasses: calibration of an empirical technique. Mineral. Petrol.

Donaldson, C.H., and Brown, R.W.. 1977. Refractory megacrysts and magnesium-rich melt inclusions within spinel in oceanic tholeiites: indications of magma mixing and parental magma composition. Earth Sci. Planet. Lett., 37:81-89.

Duncan, R.A., and Green, D.H., 1987. The genesis of refractory melts in the formation of oceanic crust. Contrib. Mineral. Petrol., 96:326-342.

Falloon, T.J., and Green, D.H., 1986. Glass inclusions in magnesian olivine phenocrysts from Tonga: evidence for highly refractory parental magmas in the Tonga arc. Earth Planet. Sci. Lett., 81:95-103.

1988. Anhydrous partial melting of peridotite from 8 to $35 \mathrm{kbar}$ and the petrogenesis of MORB. J. Petrol., 29:379-414.

Fisk, M.R., 1984. Depths and temperatures of mid-ocean ridge magma chambers and the composition of their source. In Gass, I.G., Lippard, S.J., and Shelton, A.W. (Eds.), Ophiolites and Oceanic Lithosphere. Geol. Soc. Spec. Publ. London, 13:17-23.

Ford, C.E., Russell, D.G., Craven, J.A., and Fisk, M.R. 1983. Olivine-liquid equilibria: temperature, pressure and compositional dependence of the crystal/liquid cation partition coefficients for $\mathrm{Mg}, \mathrm{Fe}^{2+}, \mathrm{Ca}$, and $\mathrm{Mn} . J$. Petrol., 24:256-265.

Gaetani, G.A., Grove, T.L., and Bryan, W.B., 1994. Experimental phase relations of basaltic andesite from Hole 839B under hydrous and anhydrous conditions. In Hawkins, J., Parson, L., Allan, J., et al., Proc. $O D P$, Sci. Results, 135: College Station, TX (Ocean Drilling Program), 557563.

Grove, T.L., and Bryan, W.B., 1983. Fractionation of pyroxene-phyric MORB at low pressure: an experimental study. Contrib. Mineral. Petrol., 84:293-309.

Grove, T.L., Gerlach, D.C., and Sando, T.W., 1982. Origin of calc-alkaline series lavas at Medicine Lake Volcano by fractionation, assimilation and mixing. Contrib. Mineral. Petrol., 80:160-182.

Haskall, K., Forsyth, L., Nielsen, R.L., and Fisk, M.R., 1993. Experimental constraints on the parental magma for the high-An feldspar bearing Lamont seamount lavas. Eos, 74:357.

Jarosewich, E.J., Nelen, J.A., and Norberg, J.A., 1980. Reference samples for electron microprobe analysis. Geostand. Newsl, 4:43-47.

Johnson, K.T.M., Fisk, M.R., and Naslund, H.R., 1995. Geochemical characteristics of refractory silicate melt inclusions from Leg 140 diabases. In 
Erzinger, J., Becker, K., Dick, H.J.B., and Stokking, L.B. (Eds.), Proc. ODP, Sci. Results, 137/140: College Station, TX (Ocean Drilling Program), 131-139.

Lavrentev, Y.G., Pospelova, L.N., and Sobolev, A.V., 1974. Rock-forming mineral compositions determination by X-ray microanalysis. Zavodsk. Lab., 40:657-666. (in Russian)

Maurel, C., and Maurel, P., 1982. Etude expérimentale de l'équilibre $\mathrm{Fe}^{2+}$ $\mathrm{Fe}^{3+}$ dans les spinelles chromiferes et les liquides silicates basiques coexistants, à $1 \mathrm{~atm}$. C. R. Acad. Sci. Ser. 2, 285:209-215.

Melson, W.G., Vallier, T.L., Wright, T.L., Byerly, G.R., and Nelen, J.A., 1976. Chemical diversity of abyssal volcanic glass erupted along Pacific, Atlantic, and Indian ocean sea-floor spreading centers. Geophys. Monogr., Am. Geophys. Union, 19:351-368.

Michael, P.J., 1988. The concentration, behavior and storage of $\mathrm{H}_{2} \mathrm{O}$ in the suboceanic upper mantle: implications for mantle metasomatism. Geochim. Cosmochim. Acta, 52:555-566.

Michael, P.J., and Chase, R.L., 1987. The influence of primary magma composition, $\mathrm{H}_{2} \mathrm{O}$ and pressure on mid-ocean ridge basalt differentiation. Contrib. Mineral. Petrol., 96:245-263.

Natland, J.H., 1989. Partial melting of a lithologically heterogeneous mantle: inferences from crystallization histories of magnesian abyssal tholeiites from the Siqueiros Fracture Zone. In Saunders, A.D., and Norry, M.J. (Eds.), Magmatism in the Ocean Basins. Geol. Soc. Spec. Publ. London, 42:41-70.

Natland, J.H., Adamson, A.C., Laverne, C., Melson, W.G., and O'Hearn, T., 1983. A compositionally nearly steady-state magma chamber at the Costa Rica Rift: evidence from basalt glass and mineral data, Deep Sea Drilling Project Sites 501, 504, and 505. In Cann, J.R., Langseth, M.G., Honnorez, J., Von Herzen, R.P., White, S.M., et al., Init. Repts. DSDP, 69: Washington (U.S. Govt. Printing Office), 811-858.

Nielsen, R., Crum, J., Bourgeois, R., Hascall, K., Forsythe, D., Christie, D.M., and Fisk, M.R., 1994. Local diversity of MORB parent magmas: evidence from melt inclusions in high-An feldspar from the Gorda Ridge. Mineral. Mag., 58A:651-652. (Abstract)

Panjasawatwong, Y., 1991. An empirical study of the effects of $\mathrm{Ca} / \mathrm{Na}, \mathrm{Al} /$ $\mathrm{Si}$, and $\mathrm{H}_{2} \mathrm{O}$ on plagioclase-melt equilibria at 5-10 kbar pressure [Ph.D. thesis]. Univ. of Tasmania, Hobart, Tasmania.

Panjasawatwong, Y., Danyushevsky, L.V., Crawford, A.J., and Harris, K.L. 1995. An experimental study of the effects of melt composition on plagioclase-melt equilibria at 5 and $10 \mathrm{kbar}$ : implications for the origin of magmatic high-An plagioclase. Contrib. Mineral. Petrol., 118:420-432.

Price, R.C., Kennedy, A.K., Riggs-Sneeringer, M., and Frey, F.A., 1986. Geochemistry of basalts from the Indian Ocean triple junction: implications for the generation and evolution of Indian Ocean ridge basalts. Earth Planet. Sci. Lett., 78:379-396.
Roedder, E., 1984. Fluid inclusions. Rev. Mineral., Mineral. Soc. Am., 12.

Shipboard Scientific Party, 1993. Site 896. In Alt, J.C., Kinoshita, H., Stokking, L.B., et al., Proc. ODP. Init. Repts., 148: College Station, TX (Ocean Drilling Program), 123-192.

Sigurdsson, H., and Schilling, J.-G., 1976. Spinels in Mid-Atlantic Ridge basalts: chemistry and occurrence. Earth Planet. Sci. Lett., 29:7-20.

Sinton, C.W., Christie, D.M., Coombs, V.L., Nielsen, R.L., and Fisk, M.R., 1993. Near-primary melt inclusions in anorthite phenocrysts from the Galapagos Platform. Earth Planet. Sci. Lett., 119:527-538.

Sinton, J.M., and Detrick, R.S., 1992. Mid-ocean ridge magma chambers. $J$. Geophys. Res.,97:197-216.

Sobolev, A.V., 1983. Petrology and geochemistry of ultramafic magmas on the examples of meimechites from the northern Siberian platform [Ph.D. thesis]. Vernadsky Inst. Geochem., Moscow, USSR.

Sobolev, A.V., and Danyushevsky, L.V., 1994. Petrology and geochemistry of boninites from the North termination of the Tonga Trench: constraints on the generation conditions of primary high-Ca boninite magmas. $J$. Petrol., 35:|181-12||.

Sobolev, A.V., Danyushevsky, L.V., Dimitriyev, L.V., and Sushevskaya, N.M., 1989. High-alumina magnesian tholeiite as the primary basalt magma at mid-ocean ridge. Geochem. Int., 26:128-133.

Sobolev, A.V., Dimitriev, L.V., Baruskov, V.L.. Nesorov, V.N., and Slutsky, A.B., 1980. The formation conditions of the high-magnesium olivines from the monomineralic fraction of the Luna 24 regolith. Proc. Lunar Planet. Sci. Conf., 11:105-116.

Sobolev, A.V., and Shimizu, N., 1993. Ultra-depleted primary melt included in an olivine from the Mid-Atlantic Ridge. Nature, 363:151-154.

Stakes, D.S., Shervais, J.W., and Hopson, C.A., 1984. The volcanic-tectonic cycle of the FAMOUS and AMAR valleys, Mid-Atlantic Ridge $\left(36^{\circ}\right.$ $47^{\prime} \mathrm{N}$ ): evidence from basalt glass and phenocryst compositional variations for a steady state magma chamber beneath the valley mid-sections, AMAR 3. J. Geophys. Res., 89:6995-7028.

Walker, D.A.. Shibata, T., and DeLong, S.E., 1979. Abyssal tholeiites from the Oceanographer Fracture Zone. II. Phase equilibria and mixing. Contrib. Mineral. Petrol., 70:111-125.

Weaver, J.S., and Langmuir, C.H., 1990. Calculation of phase equilibrium in mineral-melt systems. Computers Geosci., 16:1-19.

Date of initial receipt: 22 August 1994

Date of acceptance: 15 February 1995

Ms 148SR-106 
Table 8. Experimentally homogenized melt inclusions in plagioclase, Hole 896A.

\begin{tabular}{|c|c|c|c|c|c|c|c|c|c|c|c|c|c|c|c|c|c|}
\hline $\begin{array}{l}\text { Core, section, } \\
\text { piece no. }\end{array}$ & Experiment & Inclusion & $\mathrm{SiO}_{2}$ & $\mathrm{TiO}_{2}$ & $\mathrm{Al}_{2} \mathrm{O}_{3}$ & $\mathrm{FeO}$ & $\mathrm{MnO}$ & $\mathrm{MgO}$ & $\mathrm{CaO}$ & $\mathrm{Na}_{2} \mathrm{O}$ & $\mathrm{K}_{2} \mathrm{O}$ & $\mathrm{P}_{2} \mathrm{O}_{5}$ & $\mathrm{Cr}_{2} \mathrm{O}_{3}$ & Total & $\begin{array}{l}\mathrm{CaO} / \\
\mathrm{Na}_{2} \mathrm{O}\end{array}$ & $\begin{array}{l}\text { Host } \\
\text { An }\end{array}$ & $\begin{array}{c}\text { Temperature } \\
\left({ }^{\circ} \mathrm{C}\right)\end{array}$ \\
\hline $3 \mathrm{R}-1,4$ & P2 & A & 50.91 & 0.35 & 15.53 & 8.86 & 0.14 & 8.13 & 13.19 & 1.91 & 0.01 & 0.01 & 0.08 & 99.12 & 6.91 & 85.8 & 1210 \\
\hline $3 \mathrm{R}-1.4$ & P4 & A & 51.86 & 0.36 & 15.85 & 9.20 & 0.14 & 8.41 & 12.86 & 1.74 & 0.28 & 0.02 & 0.05 & 100.77 & 7.39 & 85.1 & 1210 \\
\hline $4 \mathrm{R}-1,2$ & P10 & A & 52.25 & 0.54 & 15.50 & 9.23 & 0.10 & 8.79 & 12.84 & 1.92 & 0.02 & 0.00 & 0.05 & 101.24 & 6.69 & 86.8 & 1200 \\
\hline $4 \mathrm{R}-1,2$ & P10 & B & 51.90 & 0.53 & 15.57 & 9.29 & 0.07 & 8.78 & 13.19 & 1.71 & 0.00 & 0.00 & 0.04 & 101.08 & 7.71 & 87.4 & 1200 \\
\hline $4 \mathrm{R}-1,2$ & P10 & C & 51.93 & 0.64 & 15.50 & 9.54 & 0.09 & 8.96 & 13.27 & 1.83 & 0.03 & 0.04 & 0.05 & 101.88 & 7.25 & 86.7 & 1200 \\
\hline $4 \mathrm{R}-1,2$ & P14 & A & 49.22 & 0.30 & 15.16 & 10.21 & 0.17 & 8.46 & 13.17 & 1.86 & 0.43 & 0.09 & 0.05 & 99.12 & 7.08 & 88.0 & 1200 \\
\hline $4 \mathrm{R}-1,2$ & P15 & A & 51.68 & 0.64 & 15.88 & 7.92 & 0.11 & 9.33 & 13.65 & 1.73 & 0.01 & 0.04 & 0.10 & 101.09 & 7.89 & 90.3 & 1205 \\
\hline $4 \mathrm{R}-1,2$ & P15 & B & 51.37 & 0.59 & 15.65 & 8.01 & 0.10 & 9.14 & 13.75 & 1.54 & 0.02 & 0.09 & 0.06 & 100.32 & 8.93 & 91.0 & 1205 \\
\hline $4 \mathrm{R}-1,2$ & P73 & 5 & 51.02 & 0.53 & 15.73 & 8.02 & 0.15 & 9.43 & 13.77 & 1.64 & 0.01 & 0.05 & 0.07 & 100.42 & 8.40 & 90.7 & 1205 \\
\hline $4 \mathrm{R}-1,2$ & P76 & 2 & 50.57 & 0.78 & 14.80 & 9.42 & 0.15 & 8.43 & 13.19 & 1.99 & 0.04 & 0.08 & 0.07 & 99.52 & $\begin{array}{l}6.63 \\
6.63\end{array}$ & 87.1 & 1195 \\
\hline $4 \mathrm{R}-1,2$ & P76 & 3 & 50.67 & 0.74 & 14.70 & 9.64 & 0.13 & 8.27 & 13.07 & 1.85 & 0.01 & 0.05 & 0.09 & 99.22 & 7.06 & 87.1 & 1195 \\
\hline $9 \mathrm{R}-1,24$ & P78 & $4 \mathrm{~A}$ & 49.94 & 0.44 & 16.37 & 9.01 & 0.12 & 9.31 & 13.54 & 1.38 & 0.12 & 0.06 & 0.04 & 100.33 & 9.81 & 93.7 & 1215 \\
\hline $9 \mathrm{R}-1,24$ & P81 & 2 & 50.59 & 0.13 & 15.53 & 9.37 & 0.16 & 9.20 & 12.90 & 1.85 & 0.03 & 0.01 & 0.09 & 99.86 & 6.97 & 92.2 & 1195 \\
\hline $9 \mathrm{R}-1,24$ & P81 & 8 & 50.80 & 0.18 & 15.21 & 10.08 & 0.17 & 8.85 & 12.62 & 1.58 & 0.27 & 0.06 & 0.07 & 99.89 & 7.99 & 92.7 & 1195 \\
\hline $9 \mathrm{R}-1,24$ & P82 & IB & 50.14 & 0.59 & 16.45 & 8.22 & 0.12 & 9.31 & 13.39 & 1.64 & 0.02 & 0.12 & 0.05 & 100.05 & 8.16 & 90.7 & 1195 \\
\hline $9 \mathrm{R}-1,24$ & P85 & 1 & 51.05 & 0.67 & 14.86 & 9.30 & 0.14 & 8.20 & 12.77 & 1.96 & 0.01 & 0.03 & 0.07 & 99.06 & 6.52 & 85.7 & 1195 \\
\hline $9 \mathrm{R}-1,24$ & P85 & 3 & 49.91 & 0.69 & 15.63 & 9.80 & 0.21 & 8.34 & 11.92 & 2.00 & 0.74 & 0.02 & 0.03 & 99.29 & 5.96 & 87.9 & 1195 \\
\hline $9 \mathrm{R}-1,24$ & P86 & 3 & 50.86 & 0.56 & 14.99 & 9.24 & 0.17 & 8.17 & 12.77 & 1.99 & 0.02 & 0.03 & 0.06 & 98.86 & 6.42 & 86.7 & 1195 \\
\hline $9 \mathrm{R}-1,24$ & P86 & 5 & 51.14 & 0.65 & 15.08 & 9.35 & 0.12 & 8.29 & 12.78 & 2.02 & 0.04 & 0.04 & 0.04 & 99.55 & 6.33 & 87.1 & 1195 \\
\hline $9 R-1,24$ & P86 & 6 & 51.27 & 0.64 & 15.01 & 9.49 & 0.12 & 8.24 & 13.02 & 2.03 & 0.03 & 0.04 & 0.05 & 99.94 & 6.41 & 87.1 & 1195 \\
\hline $25 \mathrm{R}-1,11$ & P5 & A & 51.09 & 0.77 & 15.53 & 9.12 & 0.15 & 8.69 & 12.86 & 1.91 & 0.01 & 0.00 & 0.10 & 100.23 & 6.73 & 85.9 & 1200 \\
\hline $25 \mathrm{R}-1,11$ & P61 & i & 51.31 & 0.76 & 15.19 & 8.60 & 0.16 & 8.45 & 13.19 & 2.12 & 0.04 & 0.03 & 0.04 & 99.89 & 6.22 & 84.6 & 1205 \\
\hline $25 \mathrm{R}-1,11$ & P61 & 2 & 50.74 & 0.84 & 15.12 & 8.69 & 0.18 & 8.41 & 12.98 & 2.14 & 0.04 & 0.06 & 0.03 & 99.23 & 6.07 & 84.6 & 1205 \\
\hline $25 \mathrm{R}-1.11$ & P61 & 3 & 50.70 & 0.78 & 15.04 & 8.67 & 0.11 & 8.65 & 12.95 & 2.05 & 0.03 & 0.07 & 0.08 & 99.13 & 6.32 & 87.3 & 1205 \\
\hline $25 \mathrm{R}-1,11$ & P61 & 4 & 50.96 & 0.74 & 15.02 & 8.83 & 0.10 & 8.65 & 12.97 & 1.97 & 0.02 & 0.06 & 0.04 & 99.36 & 6.58 & 86.7 & 1205 \\
\hline $25 \mathrm{R}-1,11$ & P61 & 6 & 50.89 & 0.74 & 15.09 & 8.68 & 0.12 & 8.56 & 12.93 & 2.10 & 0.03 & 0.04 & 0.07 & 99.25 & 6.16 & 83.2 & 1205 \\
\hline $25 \mathrm{R}-1,11$ & P64 & 1 & 50.29 & 0.87 & 15.09 & 9.32 & 0.14 & 8.19 & 13.03 & 2.20 & 0.01 & 0.04 & 0.05 & 99.23 & 5.92 & 79.6 & 1205 \\
\hline $27 \mathrm{R}-1,13$ & P42 & 3 & 50.64 & 0.20 & 15.56 & 8.73 & 0.16 & 8.73 & 13.19 & 1.69 & 0.04 & 0.04 & 0.08 & 99.06 & 7.80 & 89.7 & 1215 \\
\hline $27 \mathrm{R}-1,13$ & $\mathrm{P} 42$ & 7 & 49.97 & 0.28 & 15.73 & 8.69 & 0.16 & 9.18 & 12.94 & 1.69 & 0.02 & 0.03 & 0.06 & 98.75 & 7.66 & 90.1 & 1215 \\
\hline $27 \mathrm{R}-1,13$ & P45 & 1 & 50.45 & 0.23 & 15.87 & 8.57 & 0.10 & 9.14 & 13.36 & 1.67 & 0.02 & 0.00 & 0.04 & 99.45 & 8.00 & 89.9 & 1215 \\
\hline $27 \mathrm{R}-1,13$ & P45 & 2 & 50.34 & 0.20 & 15.68 & 8.63 & 0.16 & 9.28 & 12.83 & 1.71 & 0.01 & 0.01 & 0.05 & 98.90 & 7.50 & 89.4 & 1215 \\
\hline $27 \mathrm{R}-1,13$ & P45 & 4 & 50.36 & 0.24 & 15.57 & 8.41 & 0.17 & 9.34 & 13.03 & 1.67 & 0.03 & 0.01 & 0.09 & 98.92 & 7.80 & 90.7 & 1215 \\
\hline $27 \mathrm{R}-1,13$ & P45 & 5 & 50.28 & 0.22 & 15.98 & 8.39 & 0.11 & 9.31 & 13.12 & 1.60 & 0.01 & 0.00 & 0.06 & 99.08 & 8.20 & 90.4 & 1215 \\
\hline $27 \mathrm{R}-1,13$ & P45 & 6 & 50.52 & 0.19 & 15.89 & 8.18 & 0.15 & 9.23 & 13.03 & 1.55 & 0.04 & 0.00 & 0.06 & 98.84 & 8.41 & 89.8 & 1215 \\
\hline $27 \mathrm{R}-1,13$ & P45 & $7 \mathrm{~A}$ & 50.42 & 0.23 & 16.09 & 8.18 & 0.12 & 9.27 & 13.11 & 1.66 & 0.01 & 0.00 & 0.04 & 99.13 & 7.90 & 90.2 & 1215 \\
\hline $27 \mathrm{R}-1,13$ & P46 & 3 & 50.83 & 0.21 & 15.59 & 8.80 & 0.16 & 8.66 & 13.27 & 1.73 & 0.02 & 0.02 & 0.07 & 99.36 & 7.67 & 90.2 & 1210 \\
\hline $27 \mathrm{R}-1,13$ & P46 & 4 & 50.18 & 0.27 & 16.05 & 8.78 & 0.17 & 9.29 & 13.21 & 1.62 & 0.01 & 0.02 & 0.09 & 99.69 & 8.15 & 90.0 & 1210 \\
\hline $27 \mathrm{R}-1,13$ & P46 & 5 & 49.98 & 0.27 & 15.88 & 8.92 & 0.13 & 9.27 & 13.16 & 1.66 & 0.01 & 0.01 & 0.08 & 99.37 & 7.93 & 90.8 & 1210 \\
\hline $27 \mathrm{R}-1,13$ & P48 & 1 & 50.17 & 0.26 & 15.47 & 9.36 & 0.13 & 8.96 & 12.69 & 1.61 & 0.26 & 0.02 & 0.06 & 98.99 & 7.88 & 90.5 & 1210 \\
\hline $27 \mathrm{R}-1,13$ & P48 & 2 & 50.15 & 0.28 & 15.56 & 9.50 & 0.15 & 9.15 & 12.74 & 1.65 & 0.26 & 0.03 & 0.04 & 99.51 & 7.72 & 91.0 & 1210 \\
\hline $27 \mathrm{R}-1,13$ & P48 & 3 & 50.07 & 0.27 & 16.15 & 9.29 & 0.19 & 8.96 & 12.72 & 1.65 & 0.28 & 0.07 & 0.02 & 99.67 & 7.71 & 90.3 & 1210 \\
\hline $27 \mathrm{R}-1,13$ & P50 & i & 50.11 & 0.53 & 16.51 & 7.67 & 0.11 & 9.39 & 13.12 & 1.66 & 0.02 & 0.02 & 0.09 & 99.23 & 7.90 & 90.9 & 1215 \\
\hline $27 \mathrm{R}-1,13$ & P51 & 2 & 50.84 & 0.27 & 16.04 & 8.72 & 0.14 & 8.42 & 13.50 & 1.90 & 0.01 & 0.00 & 0.04 & 99.88 & 7.11 & 89.8 & 1210 \\
\hline $27 \mathrm{R}-1,13$ & P51 & 6 & 51.07 & 0.24 & 15.68 & 9.04 & 0.16 & 8.74 & 13.29 & 1.72 & 0.03 & 0.01 & 0.04 & 100.02 & 7.73 & 90.5 & 1210 \\
\hline $27 \mathrm{R}-1,15$ & P56 & 4 & 50.82 & 0.59 & 15.70 & 9.16 & 0.16 & 8.87 & 12.64 & 1.64 & 0.03 & 0.00 & 0.02 & 99.63 & 7.71 & 88.4 & 1195 \\
\hline $27 \mathrm{R}-1,15$ & P56 & 6 & 51.06 & 0.65 & 14.93 & 8.61 & 0.16 & 8.69 & 12.42 & 1.61 & 0.03 & 0.03 & 0.01 & 98.20 & 7.71 & 88.5 & 1195 \\
\hline $27 \mathrm{R}-1,15$ & P57 & i & 50.45 & 0.48 & 15.71 & 9.50 & 0.16 & 8.99 & 13.03 & 1.50 & 0.03 & 0.00 & 0.08 & 99.93 & 8.69 & 89.3 & 1205 \\
\hline $27 \mathrm{R}-1,15$ & P57 & 2 & 49.96 & 0.53 & 15.19 & 10.46 & 0.11 & 8.25 & 12.28 & 1.75 & 0.30 & 0.00 & 0.06 & 98.89 & 7.02 & 89.3 & 1205 \\
\hline $27 \mathrm{R}-1,15$ & P57 & 3 & 49.62 & 0.51 & 16.29 & 8.98 & 0.17 & 8.75 & 12.83 & 1.46 & 0.03 & 0.03 & 0.06 & 98.73 & 8.79 & 89.3 & 1205 \\
\hline $27 \mathrm{R}-1,15$ & P65 & 1 & 50.51 & 0.86 & 15.51 & 9.27 & 0.14 & 8.39 & 13.10 & 1.83 & 0.03 & 0.08 & 0.10 & 99.82 & 7.16 & 89.8 & 1205 \\
\hline $27 \mathrm{R}-1,15$ & P66 & 2 & 50.34 & 0.40 & 15.48 & 8.68 & 0.14 & 8.99 & 12.99 & 1.57 & 0.02 & 0.02 & 0.07 & 98.70 & 8.27 & 89.3 & 1200 \\
\hline $27 \mathrm{R}-1,15$ & P66 & 3 & 50.64 & 0.42 & 15.37 & 8.63 & 0.15 & 8.97 & 13.09 & 1.62 & 0.04 & 0.01 & 0.04 & 98.98 & 8.08 & 89.1 & 1200 \\
\hline $27 \mathrm{R}-1,15$ & P66 & 7 & 50.19 & 0.52 & 15.38 & 8.75 & 0.14 & 8.83 & 12.79 & 1.51 & 0.54 & 0.00 & 0.07 & 98.72 & 8.47 & 90.9 & 1200 \\
\hline $27 \mathrm{R}-1,15$ & P67 & 1 & 51.22 & 0.48 & 15.62 & 8.84 & 0.17 & 8.96 & 12.99 & 1.67 & 0.03 & 0.07 & 0.09 & 100.14 & 7.78 & 89.8 & 1205 \\
\hline $27 \mathrm{R}-1,15$ & P67 & 4 & 51.13 & 0.51 & 15.53 & 8.86 & 0.10 & 9.02 & 13.02 & 1.81 & 0.03 & 0.05 & 0.04 & 100.10 & 7.19 & 90.0 & 1205 \\
\hline $27 \mathrm{R}-1,15$ & P67 & 5 & 51.05 & 0.42 & 16.57 & 8.52 & 0.14 & 8.92 & 13.28 & 1.73 & 0.01 & 0.03 & 0.10 & 100.77 & 7.68 & 89.3 & 1205 \\
\hline $27 \mathrm{R}-1,15$ & P68 & 1 & 51.27 & 0.59 & 15.30 & 9.77 & 0.17 & 8.08 & 12.86 & 1.79 & 0.01 & 0.06 & 0.05 & 99.95 & 7.18 & 88.2 & 1200 \\
\hline $27 \mathrm{R}-1,15$ & P68 & 3 & 51.11 & 0.57 & 15.37 & 9.82 & 0.17 & 8.15 & 13.10 & 1.81 & 0.01 & 0.04 & 0.08 & 100.23 & 7.24 & 89.3 & 1200 \\
\hline $27 \mathrm{R}-1$, is & P68 & 9 & 51.52 & 0.49 & 15.12 & 9.63 & 0.12 & 8.32 & 12.88 & 1.81 & 0.04 & 0.01 & 0.04 & 99.98 & 7.12 & 89.1 & 1200 \\
\hline $27 \mathrm{R}-1,15$ & P69 & 14 & 51.26 & 0.56 & 15.03 & 9.53 & 0.16 & 8.68 & 12.76 & 1.74 & 0.01 & 0.00 & 0.07 & 99.80 & 7.33 & 89.1 & 1200 \\
\hline $27 \mathrm{R}-1,15$ & P69 & 15 & 51.31 & 0.57 & 14.99 & 9.84 & 0.17 & 8.77 & 12.90 & 1.75 & 0.01 & 0.02 & 0.09 & 100.42 & 7.37 & 89.0 & 1200 \\
\hline $27 \mathrm{R}-1,15$ & P69 & 4 & 50.64 & 0.53 & 15.46 & 9.40 & 0.15 & 8.62 & 12.76 & 1.63 & 0.02 & 0.01 & 0.05 & 99.27 & 7.83 & 89.1 & 1200 \\
\hline $27 \mathrm{R}-1,15$ & P70 & 2 & 50.34 & 0.65 & 15.98 & 9.25 & 0.15 & 8.84 & 13.27 & 1.65 & 0.02 & 0.03 & 0.07 & 100.25 & 8.04 & 90.2 & 1205 \\
\hline
\end{tabular}



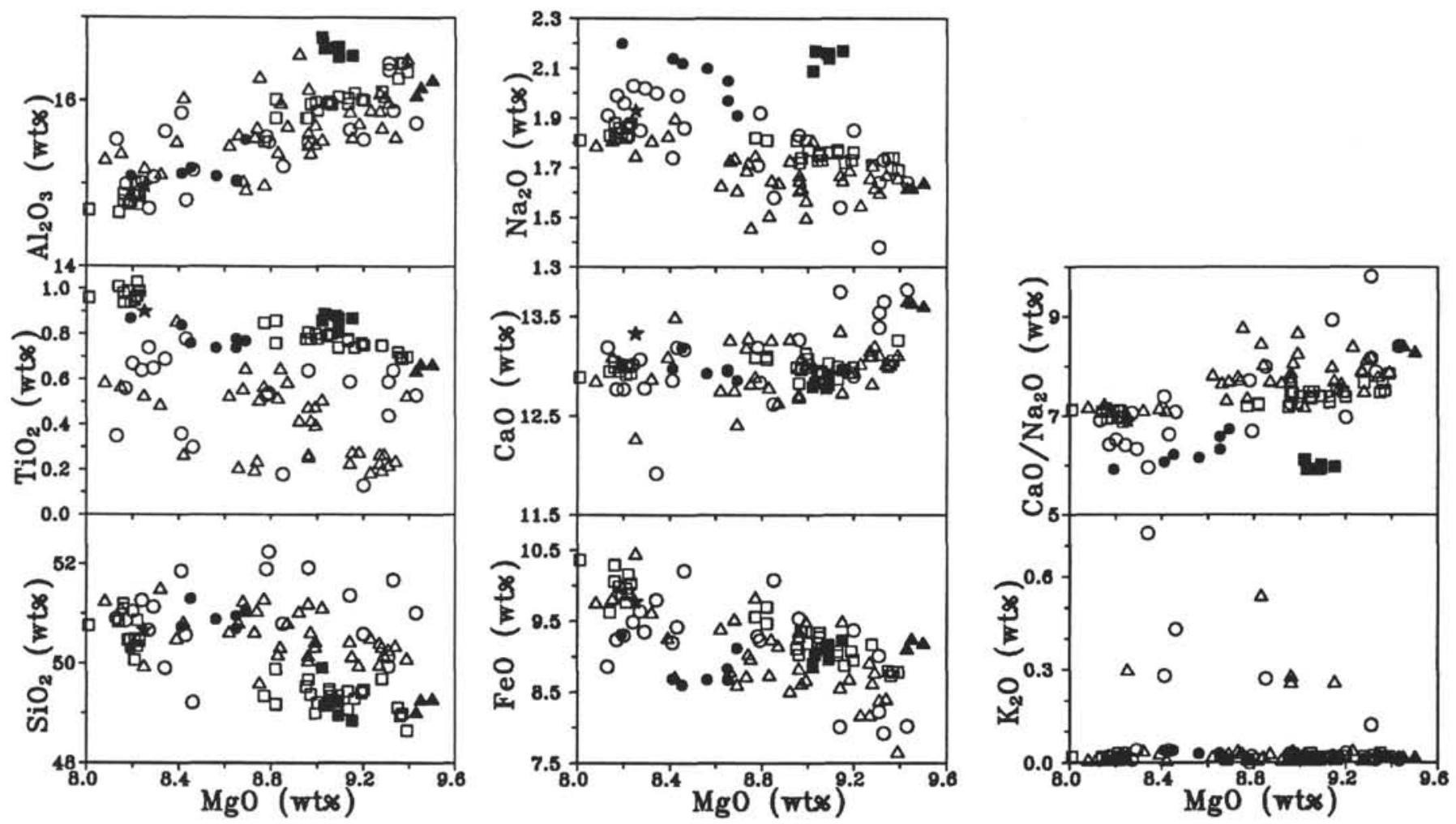

Figure 10. Compositional variations in homogenized inclusions in plagioclase unaffected by overheating, poor quenching or analytical overlap with host plagioclase. See text for discussion. Symbols as for Figure 6A. Pillowrim glasses are plotted for comparison (symbols as for Fig. 2).

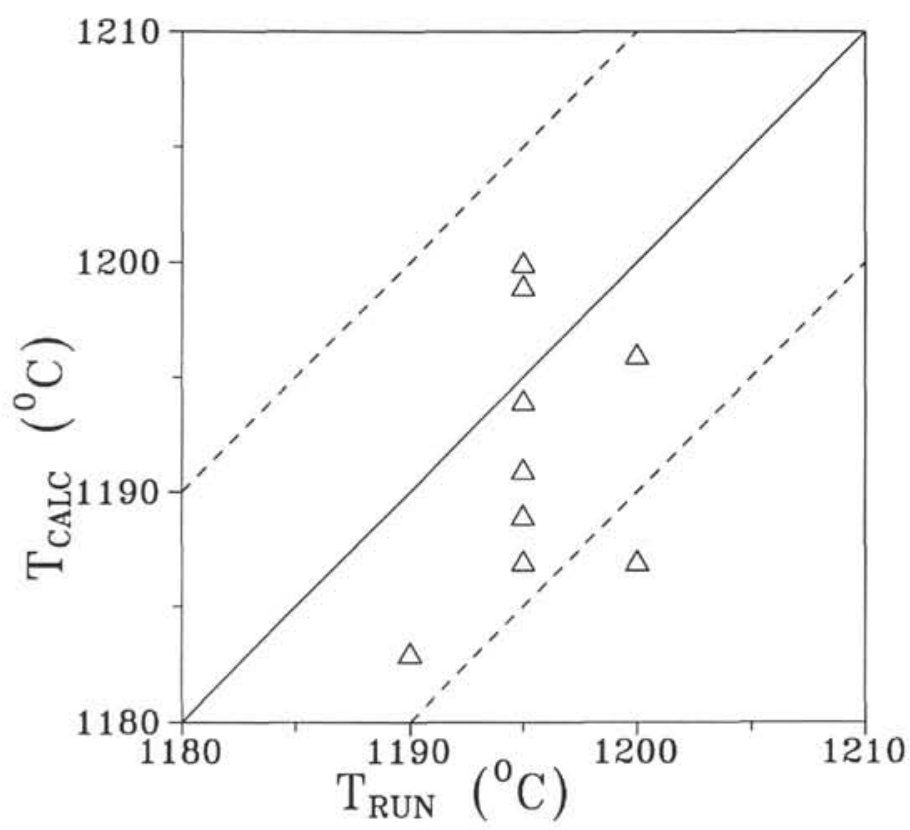

Figure 11. Comparison of calculated olivine temperature (using the geothermometer of Ford et al., 1983) and run temperature for all homogenized olivine inclusions. All results indicate equilibrium has been obtained. $\mathrm{T}_{\mathrm{CALC}}=$ calculated temperature, $\mathrm{T}_{\mathrm{RUN}}=$ run temperature. 


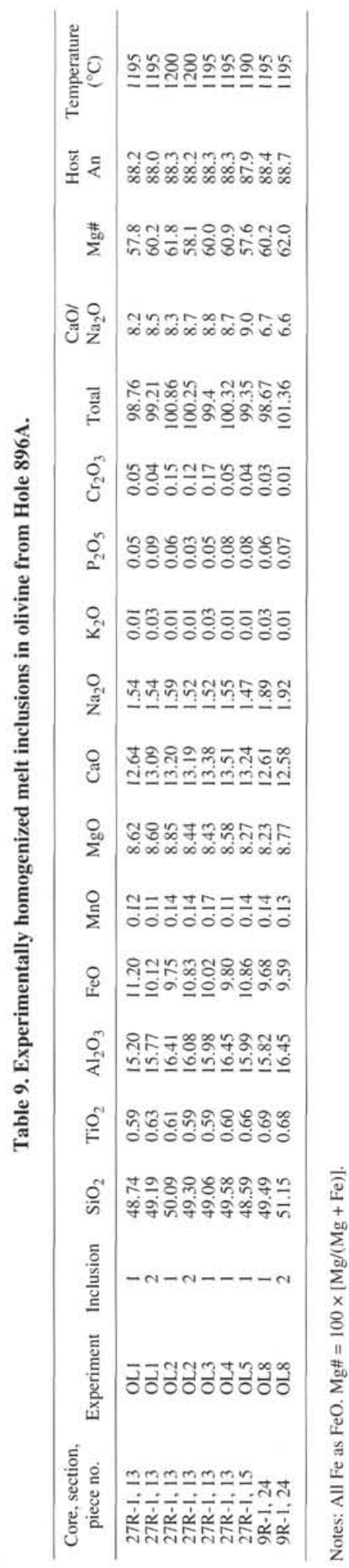

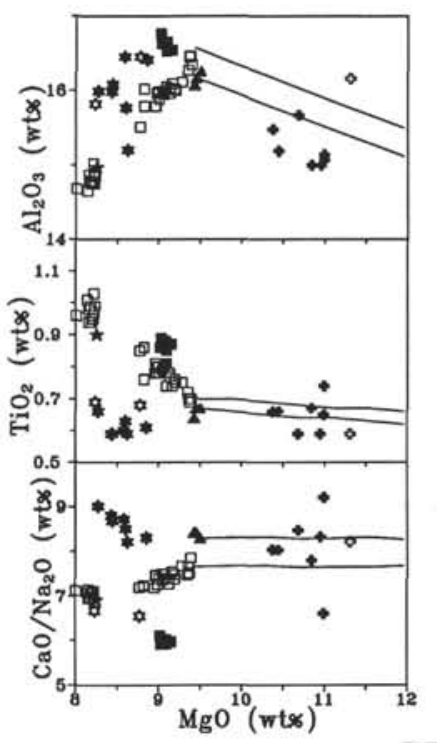

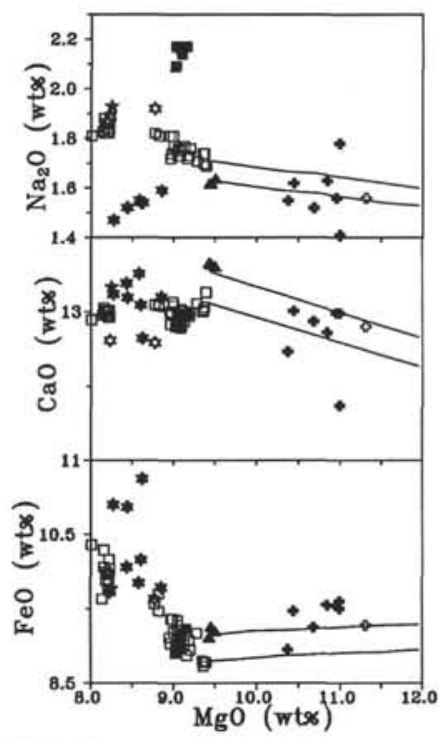

Figure 12. Compositional variations of homogenized inclusions in olivine phenocrysts. Solid stars are inclusions from Group 3, open stars are inclusions from Group 1. Pillow-rim glasses are included for comparison (see Fig. 2 for symbols). Solid and open crosses are the compositions of naturally quenched inclusions in olivine recalculated to be in equilibrium with their host. See text for calculation procedures. The solid lines show reverse fractionation paths for the most primitive glasses of Groups 1 and 3. These were calculated by the modeling of reverse of olivine only crystallization, see text for description of the technique used. Note that compositions of recalculated naturally quenched inclusions in olivines $\left(\sim \mathrm{Fo}_{88}\right)$ match these trends for all elements.

Table 10. Calculated parental melt compositions, Hole 896A.

\begin{tabular}{lrr}
\hline \multicolumn{1}{c}{ Analysis no.: } & \multicolumn{1}{c}{1} & \multicolumn{1}{c}{2} \\
\hline $\mathrm{SiO}_{2}$ & 47.84 & 48.18 \\
$\mathrm{TiO}_{2}$ & 0.57 & 0.61 \\
$\mathrm{Al}_{2} \mathrm{O}_{3}$ & 13.85 & 14.38 \\
$\mathrm{Fe}_{2} \mathrm{O}_{3}$ & 1.16 & 1.12 \\
$\mathrm{FeO}$ & 8.24 & 7.94 \\
$\mathrm{MnO}$ & 0.10 & 0.10 \\
$\mathrm{MgO}$ & 15.13 & 14.69 \\
$\mathrm{CaO}$ & 11.59 & 11.38 \\
$\mathrm{Na} 2$ & 1.40 & 1.49 \\
$\mathrm{~K}_{2} \mathrm{O}$ & 0.02 & 0.02 \\
$\mathrm{P}_{2} \mathrm{O}_{5}$ & 0.03 & 0.03 \\
$\mathrm{Cr}_{2} \mathrm{O}_{3}$ & 0.07 & 0.06 \\
$\mathrm{Total}$ & 100.00 & 100.00 \\
Calculated temperature $\left({ }^{\circ} \mathrm{C}\right)$ & 1348 & 1340 \\
& & \\
\end{tabular}

Notes: $I$ = Sample 148-896A-27R-1 (Piece 15), 2 = Sample 148-896A-3R-1 (Piece 4). 